\title{
The Control of Managerial Discretion: Evidence from Unionization's Impact on Employment Segregation
}

\author{
John-Paul Ferguson \\ Stanford University \\ Conditionally Accepted at the American Journal of Sociology
}

\begin{abstract}
Does limiting managers' discretion limit organizations' scope for discrimination? Socialpsychological research argues that it limits opportunities to exercise cognitive biases. Organizational research has found that formal personnel practices that establish accountability for workplace diversity have increased women and minority representation in management. However, drawing causal inferences from such studies is complicated because adopting such policies may be endogenous to the firm's wish to hire and promote women and minorities. This study uses unionization elections to conduct a regression-discontinuity test from which stronger causal inferences can be made. I find that while unionization is associated with more representative workplaces and more women and minorities in management, these effects disappear close to the discontinuity threshold. Most of the effects of unionization on workforce diversity may be attributable to the unobserved drivers of selection into unionization. This has similar implications for the causal effects of diversity policies adopted by managers.
\end{abstract}

Acknowledgments

The author would like to thank Emilio Castilla, Roberto Fernandez, Aruna Ranganathan, Susan Silbey, Jesper Sørensen, and seminar participants at Stanford GSB, Berkeley-Haas, MIT-Sloan, INSEAD, and the $30^{\text {th }}$ EGOS Colloquium for comments on the manuscript. Sheldon Friedman, Alfonso Nevárez, and Gordon Pavy at the NLRB and Bliss Cartwright and Ronald Edwards at the EEOC gave invaluable support with the data. Direct correspondence to John-Paul Ferguson, Stanford Graduate School of Business. Email: jpferg@stanford.edu. 


\section{Introduction}

Does limiting managerial discretion limit organizations' scope for discrimination? Much sociological and organizational theory (Reskin 2000; Reskin and Branch McBrier 2000; Bielby 2000; Reskin 2003; Dobbin 2009), supported by a growing body of empirical research (Huffman 1995; Kalev, Dobbin and Kelly 2006; Castilla 2008; Kalev 2009; Castilla and Benard 2010), suggests that it does. This work situates much employment discrimination not in the conscious actions of bigoted managers but in the unconscious impact of cognitive biases, deployed through personnel policies that fail to take such biases into account. As one classic review of the subject summarized, "We cannot rid work organizations of discrimination until we recognize both that much employment discrimination originates in automatic cognitive processes, and that it occurs because of work organizations' personnel practices" (Reskin 2000, p. 321).

This social-psychological approach to discrimination reinforces an older organizational perspective on the subject. Organizational research has long emphasized the existence of informal social structures within formal organizations (Mayo 1984; Dalton 1959; Scott and Davis 2006) and recognized that, in the absence of formal structures, informal processes like ascriptive homophily will shape organizational careers and rewards. This is why, in his unromantic defense of complex organizations, Perrow (1986, p. 6) emphasizes the importance of rules that limit managers' discretion in "Purging Particularism":

Particularism means that criteria irrelevant for efficient production (e.g., only relatives of the boss have a chance at top positions), in contrast to universalistic criteria (e.g., competence is all that counts), are used to choose employees. The criteria of efficiency and particularism are likely to clash, since the most efficient workers may lack the particular social characteristics desired.

The formal rules, objective criteria, and accountability that Perrow advocates to remove particularism closely parallel the personnel policies that Reskin (2000), Bielby (2000), and others have recommended to minimize the exercise of bias in workplace decisions: "Insofar as formal employment practices require employers to standardize procedures and achievement criteria, managerial sex composition in organizations with highly formalized personnel practices will be less affected by ascription" (Reskin and Branch Mcbrier 2000, p. 214).

For two generations, as the United States has worked to overcome centuries of racial discrimination and segregation, personnel policies like these have been elaborated time and again 
to limit authorities' personal discretion in evaluating candidates for employment, education, public office and more. Considerable empirical research has documented both the spread (Jacoby 1985; Baron, Jennings, and Dobbin 1988; Edelman, Uggen and Erlanger 1999; Kelly and Dobbin 1999) and the impact of diversity offices (Kalev et al. 2006), performance evaluations (Castilla 2008), merit-based pay and more. On balance, these studies find many of the theorized effects. It is not enough simply to tell people that their actions should be meritocratic (Castilla and Benard 2010), some best practices are better than others (Kalev et al. 2006), and such policies seem stronger when there are outside parties who can hold policymakers accountable (Edelman 1992; Huffman 1995; Kalev et al. 2006). These nuances notwithstanding, formal operating procedures that limit managers' discretion in hiring, retention and promotion seem to be associated with greater opportunities for women and ethnic minorities in firms.

Our enthusiasm for the impact of such policies should be tempered, however, by the difficulty of drawing causal inferences from the existing empirical studies of the relationship between limiting managerial discretion and employment segregation (Kalev et al. 2006; Sørensen and Sharkey 2011). Prior work has shown that firms that adopt formal diversity practices have increased employee diversity in the future. But can we say that the practices caused the change? Or rather, might executives' interest in increasing diversity have caused both the adoption of such practices and the focus on hiring and promoting women and minorities? Even in research designs that use fixed effects to control for unobserved differences among firms (Kalev et al. 2006; Kalev 2009), the endogeneity of policies to executives' preferences is difficult to control for empirically, because those preferences can change over time.

Such endogeneity is crucial for understanding the substantive impact of policies that limit managerial discretion. If adopting such a policy is independent of the firm's preferences, then it is reasonable to assume that, had the policy not been adopted, there would have been no comparable changes in workforce composition. Additionally, we could assume that applying the policy in firms that had not already applied it would produce similar effects. If on the other hand adoption of discretion-limiting policies depends on the firms' preferences-if firms self-selectthen both of these assumptions are undermined. First, we cannot assume that there would be no changes in workforce composition absent the policy, because firms might simply look for other means to achieve the same ends. Second and most important for policymakers interested in reducing employment segregation, applying such policies in firms that had not already voluntarily 
adopted them need not produce comparable effects. As our terms of debate slowly shift from what firms have done about workplace discrimination to what firms should do, it becomes imperative that we subject our theories of discrimination and its remedies to strong causal tests. To make stronger causal claims about limiting managerial discretion's effects on workforce composition, for example, we would prefer to examine the impact of policies whose imposition is exogenous to firms' goals.

This study uses a research design that makes such causal inferences more plausible. I focus on the effects of unionization on workforce composition. Unionization is a strategic phenomenon to study in light of this research because unions have frequently been theorized to have effects similar to many diversity policies. Union contracts typically limit employers' discretion over hiring, discipline, promotion and termination (Leonard 1985), exactly the reasons why many firms and executives oppose unionization. While the relationship between labor unions and minorities has historically been complicated (Botsch 1980; Nelson 2001), unions remain among the most integrated institutions in American society, and minorities frequently express support for unions because they reduce employers' arbitrary authority (Freeman and Rogers 1999; Milkman 2006; Rosenfeld and Kleykamp 2012). Studies of diversity policies typically control for the presence of unions in firms, precisely because unions are theorized to have similar effects on the formalization of employment (Dobbin and Sutton 1998). More importantly for the research design, unions, considered as a type of employment practice that limits managers' discretion, allow for stronger causal claims than policies promulgated by management. First, almost by definition, employers do not choose to be unionized. Second, American workplaces are most often unionized through representation elections overseen by the National Labor Relations Board (NLRB). ${ }^{1}$ Elections allow for a regression-discontinuity approach: by focusing on close elections, ones often decided by one or two votes, I examine two groups of organizations that differ almost solely on the establishment of a labor union. Changes in workforce composition between these two groups over time can

\footnotetext{
1 The National Labor Relations Act (NLRA) also allows for "voluntary recognition" of a union by an employer. In recent years, unions have sometimes chosen to forego the NLRB election procedure and instead engage in tactics that end in some sort of voluntary recognition by the employer. While such drives have increased (Brudney 2005) and attracted considerable scholarly attention (Eaton and Kriesky 2001; Milkman and Voss 2004; Martin 2008), basic information such as the number of voluntary drives per year is still difficult to collect. Such studies agree though that between 80 and 90 percent of union organizing drives still unfold within the NLRB's election framework.
} 
more plausibly be attributed to the union's presence than to self-selection or some other endogenous process.

I focus on establishments with more than 100 employees that were targeted by unionorganizing drives between 1984 and 2008. Establishments of this size are required to file annual employment surveys with the Equal Employment Opportunity Commission (EEOC) that detail the racial and sexual composition of their workforce in several broad occupational categories, which means that I can track their workforce composition over time, in the wake of union organizing or its failure. I examine unionization's effects on three measures: the shares of women and minorities among managers, occupational segregation within the establishment, and the composition of the establishment workforce relative to its larger labor market.

I find contradictory effects of unionization. Consistent with prior research both on the impact of unionization (Leonard 1985) and on the impact of policies that limit managerial discretion (Kalev et al. 2006), I find that establishments where unions are formed become more representative of their larger labor markets over time. Unionized establishments also tend to increase the proportion of women and minorities filling managerial functions over time, relative to establishments where unionization failed. These effects are visible in the full population of establishments targeted by union-organizing drives. There are however differences between the average firm where unionization succeeds and where it fails: union organizing is more successful in more segregated establishments and in firms that already have more female and minority managers. This suggests that the relationship between the union and the workforce's make-up may be spurious. When I focus on close elections, those near the discontinuity, the apparent effects of unionization disappear. Taken together, these trends suggest that the population-level effects of unions are best understood as stemming from the characteristics of the establishments whose workers opt for unionizing. In other words, the apparent effects of unions can probably be explained by self-selection into unionization.

This study thus makes two contributions to our understanding of employment segregation. First, it investigates the relationship between unionization and workforce composition on a larger scale and with more fine-grained data than has heretofore been possible. Given the long-standing debates about how unions affect workforce diversity (Leonard 1985; Milkman 1987; Nelson 2001; Rosenfeld and Kleykamp 2012), such an investigation is long overdue. Second, it suggests serious caution in interpreting previous work on the effects of managerial diversity policies. It is true that 
unionization is often indirectly related to diversity, but it is also true that the process of unionizing is far less likely to be driven by self-selection than managerial programs are. If we find selfselection in this setting-and I do-then we should be alert that it is even more likely where managers choose to adopt policies. If sociology is to continue its defense of limiting managerial discretion as a bulwark against ascriptive discrimination, it will need new results, with different study designs, than what have come before.

\section{Managerial discretion and employment discrimination: from mechanisms to effects to causes}

A key presumption of formal, bureaucratic employment policies is that a person's ability to perform a job well is more important than and separable from the influence and sympathy that their interpersonal affiliations can provide (Weber 1968). Few scholars doubt the desirability of formal and meritocratic administration, but many question how easily it can be carried out.

Social-psychological research has uncovered a range of unconscious biases-social categorization, in-group preference, stereotyping, and attribution bias (Fiske 1998) - that people deploy when evaluating others. Such biases mean that managers, even ones who are not consciously prejudiced, are unlikely to make personnel decisions solely on merit when left to their own discretion (Castilla and Benard 2010). Instead, the mental "shortcuts" (Reskin 2000) they deploy will tend to produce outcomes that systematically privilege the employment and promotion of already-privileged groups, such as white men. Such biases will be all the stronger in workplaces that emphasize collegial and informal affiliation, rather than formal, bureaucratic organization (Cook and Waters 1998; Baron, Hannan, Hsu, and Koçak 2007). It is from the recognition of these two facts-that merit should be rewarded more than ascriptive affiliation, and that we unconsciously favor ascriptive affiliation - that the dominant sociological recommendation for fighting employment discrimination emerges: "The implications of studies like these for workplace practices are clear: First, the task is not to eliminate 'stereotypical thinking' (it can't be done), but rather to minimize its impact on personnel decisions" (Bielby 2000, p. 122).

Minimizing the impact of "stereotypical thinking" is best done through limiting the discretion that managers can exercise, through monitoring their actions, defining objective standards and formal decision rules, and holding them accountable for their decisions. Thus for example in their study of layoff decisions, Elvira and Zatzick (2002) argue that "Our findings 
suggest that monitoring personnel decisions can reduce racial inequality" (p. 329), and in an experimental setting Castilla and Benard (2010) find that reminding managers of the effects of their discretion makes them less likely to deploy cognitive biases. Bielby (2000) summarizes prior research showing that "minimizing bias is especially difficult when the criteria for decision making are arbitrary and subjective" (p. 122), and calls for organizations to define objective standards for evaluation (See also Tomaskovic-Devey 1993; Reskin 2000; Baron et al. 2007). Virtually all research into employment discrimination agrees that institutions that enable workers to hold managers accountable for their decisions are among the most effective means to minimize biased behavior. The bureaucratic policies associated with internal labor markets attach paper trails to managers' decisions (Dobbin, Sutton, Meyer, and Scott 1993), publicize them (Huffman 1995), and force managers to justify them both to workers and to their own superiors (Reskin 2003). Kalev et al. (2006) make this point forcefully in comparing accountability to other mechanisms: "Programs establishing organizational responsibility are more broadly effective than those that address managerial bias or social isolation among women and African Americans. Organizations that structure responsibility see consistent positive effects for white women, black women, and black men" (p. 605).

Organizational practice has largely been justified by reference to these types of mechanisms. For the United States, the Civil Rights movement marked a turning point after which increasingly regulated, bureaucratic management was imported into the employment relationships of private firms (Lichtenstein 2002; Piore and Safford 2006; Dobbin 2009). The elaboration of case law in the last half century has eroded the at-will employment doctrine (Budd 2004). The government's outlawing of discrimination provided an opportunity for humanresource professionals to develop a new rational account about why diversity was not only meritocratic but also a source of new and better ideas for the firm (Dobbin and Sutton 1998). Furthermore, bureaucratic employment practices generate detailed records of their own logic and operations-precisely the kind of legible (Scott 1998) accounts that regulatory bodies like to see. The confluence of theory about the mechanisms of discrimination and regulatory practices meant to combat it has led some researchers to assert a rare degree of consensus within organizational scholarship and practice about how to address the problem: "We know how to change workplace policies and practices to reduce bias-when and where we have the will to do so" (Bielby 2000, p. 120; though compare Blank, Dabady and Citro 2004). 


\section{From mechanisms to effects}

While there is much theoretical agreement about the mechanisms that produce employment discrimination, there is far less empirical agreement on the effects of different proposals to reduce it. Most early research on employment discrimination studied either the incidence of segregation or the spread of diversity practices, but not both. Thus for example Kanter (1977) detailed the mechanisms that produce sex segregation and Baron and Bielby (1985) explored the sex-typing of jobs in the California civil service, while Reskin and Roos (1990), Tomaskovic-Devey (1993), and Reskin (2000) built theoretical models for managers' biased decision-making and documented continuing sexual and racial inequality in employment. Meanwhile, studies by Jacoby (1985) and Baron et al. (1988) documented the elaboration of bureaucratic personnel systems in American industry, and Edelman (1990); Dobbin and Sutton (1998); Edelman, Uggen, and Erlanger (1999); and Kelley and Dobbin (1999) charted the diffusion of diversity and equal-opportunity practices resulting from the "rights revolution" (Lichtenstein 2002) of the 1960s and 1970s. This parallel approach presumes that the spread of bureaucratic personnel systems in general and diversity policies in particular tends to reduce employment discrimination. Kavel et al. (2006) nicely characterized the risk in this presumption:

Scholars often presume practices designed to attack known causes of equality will actually reduce it...making a leap of faith between causes and remedies. Thus, for example, although we know from experimental psychology that unconscious bias is endemic, we can only hope that the prevailing treatments...diminish inequality....Whether a prescription for inequality is effective is an inherently empirical question. Current prescriptions are not based in evidence (p. 591, emphasis added).

This claim echoes Huffman's (1995) a decade earlier: "I have found little empirical research that formally tests the salience of bureaucratic employment practices for explaining gender inequality in workplace supervisory authority" (p. 382).

Given the thinness of empirical evidence, an important advance in recent years has involved marrying data on firm practices to data on workforce composition, in order to test more directly what impact specific practices have had. Most such work has used the Equal Employment Opportunity Commission's “EEO-1 surveys,” which large establishments are required to file annually and which detail the racial and sexual composition of an establishment's workforce in 
several occupational categories (Robinson et al. 2005). In addition to allowing us to "document desegregation" at a more fine-grained level than before (Tomaskovic-Devey et al. 2006; see also Cohen, Huffman, and Knauer 2009), these data have been used to directly test the effects of different organizational practices on the promotion of women and minorities in the workplace (Kalev et al. 2006; Kalev 2009; Huffman, Cohen, and Pearlman 2010).

These studies set the current standard for research into the effects of limiting managerial discretion on employment discrimination. A particular advantage of the studies by Kalev et al. (2006); Kalev (2009); and Huffman et al. (2010) is that they exploit the longitudinal structure of the EEO-1 reports to estimate models that control for unobserved differences between firms. This removes a massive empirical obstacle to identifying causal effects of bureaucratic employment practices, namely, that the spread of such practices and the change in levels of employment discrimination happen alongside changes in the population of firms.

These studies show many of the relationships that organizational theorists of discrimination have hypothesized. Huffman et al. (2010) demonstrate that progress particularly on gender desegregation has been driven by changes within firms over time rather than by the entry of integrated firms and the exit of segregated ones. Kalev et al.'s (2006) longitudinal study explores the policies behind such desegregation, and argues that policies that establish managerial responsibility through plans, formal committees and staff positions tend to increase managerial diversity; policies that raise awareness of diversity without assigning responsibility for outcomes do not. This is quite consistent with Bielby's (2000) claim that minimizing the impact of stereotypical thinking is more important than minimizing the thinking itself. Similarly, Kalev's (2009) study of the effects of work reorganization finds that job redesign that gives women workers formerly male-typed tasks is associated with increases in women's representation in management. In each of these cases, structures that limit managers' discretion, either in hiring, assigning or promoting workers, are associated with increased diversity within the higher ranks of the firm.

\section{From effects to causation}

The firm fixed effects that these studies use make it possible to control for any time-invariant differences between firms that make some more likely both to adopt such practices and to change their workforce composition than others, within the limits of the recall bias of retrospective 
surveys. While they help with such unobserved heterogeneity, fixed effects are less useful for dealing with the potential endogeneity of firms' choices. To see why this is a problem, it is useful to consider two scenarios:

- In scenario 1, firms have no interest in adopting practices that limit managerial discretion, but for various reasons are compelled to. It is observed that firms that adopt the practices see outcomes over time such as greater representation of women and minorities in management, more representative workforces and so on.

- In scenario 2, firms that want to achieve the aforementioned outcomes decide to put into place policies that they think will help them do so. Thus for example senior managers require lower-level managers to document all of their interviewing and hiring decisions, to show that no bias was exercised. It is observed that firms that adopt the policies see those outcomes over time.

In both scenarios, the same relationship between policies and outcomes is observed. In the second scenario, though, it is wrong to assume that adopting the policy had a causal impact on workforce composition, because both adoption and impact are endogenous to managerial preferences. Focusing on observational variation in adoption is flawed because of such endogeneity. Fixed effects cannot get around such a problem. Fixed effects may not even correctly identify the unobserved heterogeneity in firms' propensity to adopt such practices, if that propensity changes over time.

This is the present challenge for research on this topic: while there are a well-theorized set of mechanisms that produce employment discrimination and there is some empirical research showing that policies acting upon those mechanisms are associated with less discrimination, the possibility of endogeneity makes causal inference from this work difficult. To explore how much self-selection drives the impact of such policies, we would prefer to consider practices whose adoption is as orthogonal to managerial interests and uncorrelated with unobserved heterogeneity as possible. I propose here that unionization is such a practice.

\section{Unions and managerial discretion}

Modern corporate diversity policies were not adopted in a vacuum. For a generation before the Civil Rights movement, managers and trade unions had been developing their own systems of 
industrial jurisprudence (Jacoby 1985), and elements of the labor-relations regime often served as templates for new practices. Edelman (1990) for example studied how civil-rights grievance procedures in firms were often explicitly modeled on union grievance procedures. Thirty years before, Slichter, Healy, and Livernash (1960) popularized a theory of how, in an era of mass unionization, "rational" employment practices that were developed during collective bargaining in unionized firms diffused into non-unionized ones, partly as those firms sought to avoid unionization by offering specific employment practices and thus snatching arrows from the union's quiver.

I argue here that unionization is a theoretically and empirically useful policy change to compare to other policies that affect managers' discretion about personnel decisions. Many of the contract provisions that unions negotiate have direct implications for the composition of firms' workforces. "The most obvious way unions can affect the demographic composition of the work force is by directly controlling hiring....Even a union with no direct influence on hiring is likely to affect wages, promotions, layoffs, grievance handling, and other working conditions of direct concern to potential employees" (Leonard 1985, p. 116). Seniority systems, a common component of many union contracts, dictated the order in which employers can promote and lay off workers (Abraham and Medoff 1984). For women and minorities, such practices were and are a doubleedged sword: seniority systems historically meant that they were often the first to be laid off, but if they could accumulate seniority then the protections were considerable (Milkman 1987). More generally, unions' presence reduces employers' use of casual labor, in which women and minorities have often been disproportionately represented (Zeiger 1986; Nelson 1992). The industrial unions, which brought together skilled and more-replaceable unskilled workers in the same bargaining units, gave positions typically held by minorities more power to determine their own employment conditions (Boyle 1995; Nelson 2001). And of course labor has long had a codependent if not always cooperative relationship with the Civil Rights movement, one in which unions have often mobilized their memberships around issues relating to racial or sexual discrimination (Clawson 2003; Fantasia and Voss 2004; Frymer 2007).

Minority workers have been well aware of the advantages that union membership can offer them. Isaac, McDonald, and Lukasik (2006) have used time-series data to argue that the militant zeitgeist of the Civil Rights era was carried over into minority enrollment in unions (in the public sector in particular), as non-white workers increasingly used the machinery of collective 
bargaining to win better treatment from their employers. Freeman and Medoff (1984) noted the greater propensity of black workers to vote for unionization, and Freeman and Rogers (1999) used survey data to support the claim that black workers were drawn to unions as much for their ability to limit employers' arbitrary exercises of power as for the wage premiums in union contracts. Rosenfeld and Kleykamp (2012) have similarly argued with more recent data that black workers disproportionately benefited from union wage premiums, especially in industries where managers have had greater latitude in wage-setting. In a similar vein, Milkman's (2006) study of the SEIU's Justice for Janitors mobilization in Los Angeles had employment security as a goal alongside higher pay.

Managers have traditionally opposed unions in part because union contracts place boundaries on managerial discretion (Chamberlain 1948), a fact that prior research on employment discrimination has also made:

I am constantly surprised at the number of very large companies that make personnel decisions based on highly arbitrary and subjective criteria. These latter companies are typically ones that emphasize both a strong organizational culture and union avoidance, and whose senior executives view any move toward structured policy as a threat to management discretion (Bielby 2000, p. 127).

Attempts to introduce more flexible work arrangements in American workplaces-involving more broadly defined jobs, promotion on merit rather than seniority, and pay for performance-have repeatedly brought managers and unions into conflict because they have involved rolling back formal rules and "objective" criteria used for making decisions under the older union regime (Kochan, Katz, and McKersie 1986). Studies that explore the impact of diversity practices have considered unionization as an important potential confound, because it is theorized to produce some similar changes in the employment relationship. Thus for example Dobbin and Sutton (1998) point out that "Complex labor controls during World War II led employers to establish bureaucratic personnel offices and systems, which personnel specialists heralded for their capacity to rationalize hiring and promotion even after wartime labor controls were removed" (p. 444). Similarly, human-resource managers sold diversity practices to others in the firm as a way to demonstrate corporate commitment to the sort of formal, "rational" employment practices that unions had tended to put into place, without the unions themselves (Foulkes 1980). 
These types of research suggest that unionization, because it limits managers' discretion around issues of hiring, firing and promotion, has the potential to affect the composition of establishments' workforces in ways similar to managerial diversity policies. It is nonetheless important to acknowledge the differences between unionization and such policies, and to think through how they might influence a comparison of the two. I discuss four such differences here.

The first and potentially most fundamental difference is that, while a managerial diversity policy explicitly intends to change workforce composition, a union-organizing drive rarely does. Employees may support a union in the hope of higher pay, better benefits, more stable employment, or other issues, but they rarely do so in the hope of changing the composition of the workforce. The closest that unions ever come to having a direct say in personnel decisions is through institutions like the union hiring hall, wherein the union sends members to employers in response to requests for workers. Some hiring halls still exist in the maritime industries and a few of the building trades, but they are quite rare and were never the norm across organized establishments. Similarly, unions rarely if ever have a direct say in promotion decisions, particularly promotions into management (the 1947 Taft-Hartley Act prohibited supervisory employees from unionizing). Additionally, policies that can be interpreted as explicitly discriminatory against a legally recognized group of people are prohibited issues for collective bargaining (Edwards 1973). All of these stipulations imply that we should not expect something so straightforward as the employer and the union sitting down and hammering out a plan to change the complexion of the workforce.

It is important to emphasize, though, that sociological approaches to reducing employment segregation rely less on explicit commitments to diversity than on the rationalization of organizational practices, and the appeal to objective criteria and limited individual discretion that such rationalization entails. The key finding in Kalev et al. (2006) for example is that sensitivity training and mentorship initiatives are less effective at changing the composition of management than the drafting of plans and the creation of bodies to monitor compliance. Similarly, Kalev's (2009) investigation of work restructuring found that work reorganization significantly increased managerial opportunities for women, even though the reorganizations in question were not designed to affect women's promotion chances. In that particular case, it was the move away from traditional (and traditionally gender-typed) divisions of labor that indirectly opened up such opportunities. Castilla and Benard's (2010) experiments into the effects of meritocracy on 
performance evaluations show that stressing managers' accountability for their actions is sufficient to dampen gender discrimination in awarding performance bonuses, without mentioning gender equity as such. In these and other studies it is the indirect effects of rationalizing personnel practices and limiting managers' discretion that is theorized to drive much of the observed changes. It is because of this that I think this first difference between unionization and managerial diversity policies is not insurmountable. Unions do not target employment composition directly, but they do tend to formalize employment, to hold managers accountable for firings and promotions (through grievance if not through ex ante mechanisms), and to standardize hours, wages, and working conditions. This pattern of rationalization made corporate industrialrelations systems an appealing template for early HR managers who designed diversity programs (Dobbin 2009).

The second difference is that unions have grown weaker over time, and the contracts that they negotiate have generally become less strict and binding on employers. Kochan, Katz, and McKersie (1986) documented how, starting in the early 1980s, many unions in manufacturing gradually abandoned the more elaborate provisions of "job control" in their contracts. Thus where an auto firm might previously have recognized dozens of different job titles on the assembly line, each with a narrowly circumscribed list of duties and each with a slight distinction in pay, a new contract might recognize just three to five, with a broad range of duties and considerable scope for performance-based pay within each (See also Heckscher 1988). Senioritybased promotion systems have become less common in union contracts. More classic indicators of union strength, such as overall union density or the union wage premium, have declined over time (Eren 2007).

The third difference is that unions have not always had the best interests of women and minorities at heart. Seniority systems may reduce managerial discretion, but the "objective" criteria they reward can easily favor established, white, male employees over newcomers. Historically, seniority clauses were seen as conflicting with the drive to desegregate employment, and some of the earliest uses of affirmative action were against the exclusionary hiring practices of the building-trades unions in Philadelphia (Schuwerk 1972). The job control of union contracts often implicitly reserved certain types of work for certain ascriptive groups, for example channeling women into less skilled or less lucrative jobs (Milkman 1987; Vallas 2003). For much of the period studied here, the AFL-CIO's positions on immigration and trade were quite 
protectionist; the federation only switched to favor amnesty for illegal immigrants in 2000 . Employers have been happy to exploit ethnic, racial and sexual divisions in their workforces to divide and rule, frequently by favoring unionization among some-but not all-of their workforce (Botsch 1980; Griffith 1988; Nelson 2001; Lichtenstein 2002).

It is useful to consider these two differences together. Union job control and seniority systems have become weaker, which would seem to limit unions' ability to affect personnel composition. Yet both institutions were sometimes used to preserve racial exclusion, so the actual impact of their decline seems ambiguous. Unions have been less able to negotiate large wage and benefit increases in recent decades. Yet partly because they can promise fewer such rewards to their members, unions have increasingly tried to sell themselves as advocates for other employee rights guaranteed by other legislation, such as non-discrimination (Geoghegan 1991; Nelson 2001; Clawson 2003; Milkman 2006). Thus while some mechanisms in which union relations resemble diversity programs-such as encouraging rule-bound criteria for job assignment and promotionhave become weaker, others-such as creating intra-organizational entities that monitor compliance with obligations-have grown stronger. There is a case to be made that unions, though weaker, are also more committed to principles like integration than they were in the past, and thus that they can have an impact comparable to managerial policies.

The fourth difference is less fundamental but still important. Managerial policies typically cover most or all establishment employees. A union contract can cover all non-supervisory workers at best, and a small subset of those at worst. Even were unions to have identical impacts on workforce composition within their scope, the fact that they cover fewer employees could mean that their effects on the establishment as a whole would appear weaker. I describe this effect as less fundamental because it implies a quantitative difference in degree of coverage, rather than a qualitative difference in the policies that the union's presence influences. Because I know both the size of the proposed bargaining unit targeted by a union organizing drive and the total size of the establishment, I can also explore what if any bias this difference introduces in the available data. Additionally, because many firms' diversity policies target the managerial ranks, any comparison should focus not on the overall extent of policy coverage but on how coverage of the targeted group would affect outcome variables like overall or managerial diversity.

All four of these differences between unionization and managerial diversity polices would tend to reduce any observed effect that unions have on reducing segregation within the firm. 
Obviously, if successful union elections are not associated with changes in employment composition, this would be insufficient to make us doubt the efficacy of managerial diversity policies. The lack of effects from unionization could simply reflect these differences. The design of this study though is to examine whether we see effects of successful union-organizing drives in the full observable population, then zoom in closer to the election-success threshold to see whether those effects persist where we can rule out endogeneity from self-selection. As mentioned in the introduction, I do find full-population effects from unionization that parallel those associated with managerial policies. Those effects are attenuated closer to the threshold. Only insofar as any of these differences are more likely to matter in establishments that experienced particularly close elections should we think of this as a particularly conservative test. I discuss supplementary analyses to explore whether such idiosyncrasies exist in close-election establishments when I review my results.

It is worth considering what previous research on the effects of unions on employment composition has found. In one of the first studies to use EEOC records to track establishment composition over time, Leonard (1985) compared the workforces of union and non-union manufacturing plants in California over the late 1970s and early 1980s. His main finding was that, "With the exception of Hispanic females, unions have not been a significant impediment to minority or female blue-collar employment. In the case of black males, the employment share has increased significantly faster in union than in nonunion plants" (p. 115). Leonard also found that the presence of union seniority systems did not seem to retard the growth of minority employment, suggesting that, "Apparently, seniority provisions need not always be in conflict with the employment of minorities and women" (p. 120).

A surprising result in Leonard's (1985) study was that the representation of blacks and women among managers also increased faster in union plants than non-union ones. Kalev's (2009) more recent study finds a similar result, specifically that the share of white male managers decreases in the wake of unionization. Kalev et al.'s (2006) results are more ambiguous: unions are associated with fewer white female managers and have non-significant, negative effects on all other categories, including white men. These studies' results for managerial composition are initially surprising because, while unions can have a direct influence on the parts of the workforce covered in a collective bargaining agreement, unions do not cover managerial employees. Both authors discuss the pathways by which unionization can indirectly affect the composition of 
management-promotion from within, the desire to have managers who share characteristics with the workforce, changing demographics of the neighborhoods where establishments are located and so on. (Neither explicitly discusses the possibility that establishments with more minority representation in management will be more likely to unionize in the first place.)

It is possible therefore to make several predictions about the effects of unionization on workforce composition, given the findings of previous research. First, Leonard's (1985) longitudinal analysis of establishment composition, the historical study of union-membership patterns (Rosenfeld and Kleykamp 2009; Rosenfeld and Kleykamp 2012), and multiple case studies (Halpern 1997; Nelson 2001; Milkman 2006) all suggest that unionizing an establishment should limit managerial discretion in hiring, pay, and promotion, and thus make establishments more representative of their larger labor-market areas over time. Second, the findings in Leonard (1985) and Kalev (2009) suggest that unionization is associated with increased shares of minority and (possibly) women managers over time. Finally, it is unclear what if any effect unionization has on occupational segregation within an establishment. Unions can directly and indirectly influence hiring into the parts of the establishment where their contract applies, but they do not necessarily control hiring or lateral movement into other parts.

It is a sad irony that, in the same period when unions have grown more diverse and inclusive, their influence has shrunk. Nonetheless the unique characteristics of unionized establishments-workplaces where policies that limit managerial discretion are in place but where those policies were not endogenously chosen by management-make them an excellent place to look for those policies' effects on segregation.

\section{Data and methods}

\section{Data sources}

I track changes in establishment workforce composition over time, across the firm and relative to the larger labor market, in the wake of a union-organizing campaign. The primary data for this study come from three sources. Data on union-organizing drives are drawn from the AFL-CIO and the NLRB. Data on establishments' racial composition come from firms' EEO-1 surveys filed with the EEOC. The racial composition of MSAs is built using results from the Current Population Survey (CPS). 
Union organizing at an establishment begins with a so-called card drive, in which the union $^{2}$ tries to get employees in the proposed bargaining unit to sign cards showing their support for the NLRB to hold a secret-ballot election, in which employees can vote whether the union should be their representative for collective bargaining with their employer. Once 30 percent or more of the employees have signed such cards, the union can petition the NLRB to hold such an election. A simple majority of votes cast determines the outcome. If the union wins then the NLRB certifies the union as the employees' representative, and the employer is mandated to bargain "in good faith" with the union for one year. The goal during this period is typically a contract between the union and the employer that covers various terms and conditions of employment (McGuiness and Norris (1986) review the legal procedure in detail).

The NLRB opens a representation case when it receives such an election petition. It closes the case upon the election's result, or if the petition is withdrawn at any stage. This means that the NLRB's records contain elections where the unions lost as well as where they won. This case information has been stored in several databases over time. Since 1999, the NLRB has used the Case Activity Tracking System, or CATS database, and since 2009 has made all CATS records available in XML format through http://data.gov, the federal government's digital clearinghouse. From 1984 through 1998 NLRB data was saved in the Case Handling Information Processing System, or CHIPS database. While the NLRB no longer makes CHIPS data available, the AFL-CIO maintains copies of older election cases as part of a data-sharing agreement it signed with the NLRB in the 1960 s. $^{3}$ For this analysis I use data from both the CHIPS and the CATS databases. NLRB records from before 1984 often lack the detailed address information necessary to link organizing-drive records to the EEOC's establishment surveys. My population of firms that were targeted by organizing drives runs from 1984 through 2010; I use organizing drives that happened at establishments up to and through 2008 , so that each establishment has at least two years' post-election data in which to observe any changes in workforce composition. In robustness checks, I discuss a subset of these organizing drives for which first-contract negotiation information is also available.

\footnotetext{
2 Under the NLRA, an individual or an employer can also petition the NLRB to hold an election. In practice, unions file the overwhelming majority of petitions.

${ }^{3}$ I thank Gordon Pavy, Sheldon Friedman, and Alfonso Nevarez at the AFL-CIO for access to and help with these data.
} 
The Civil Rights Act (amended) of 1964 requires employers with more than 100 employees to file annual EEO-1 reports with the EEOC. ${ }^{4}$ These reports include a matrix that details the race and sex of employees across nine broad occupational categories. These are the most detailed establishment-level data on workforce composition available (Robinson et al. 2005), and have been used in multiple studies in particular of women and minorities' progress into management (Kalev et al. 2006; Cohen et al. 2009; Huffman et al. 2010). The focus of this study differs in that I examine the non-managerial workforce described in the reports, as well. I obtained EEO-1 data from the EEOC through an Intergovernmental Personnel Act (IPA) agreement.

To link the two data sources, I match the NLRB's representation cases with the EEO-1 surveys. Unions filed 66,097 election petitions with the NLRB between 1984 and 2008. Election petitions can be filed at workplaces that have already been unionized, for example to decertify one union and certify another. Nearly eighteen thousand of the petitions had some sort of incumbent listed on the ballot. Because my focus is on the introduction of bureaucracy through unionization, I exclude such establishments. ${ }^{5}$ The EEOC's surveys only cover large establishments; thus many NLRB records will have no match in the EEOC data because the corresponding establishment is below the latter's employment threshold. For example, only 7,223 of the NLRB's 48,251 firstelection cases involve more than 100 eligible voters. I used the approximate-string-matching algorithm in Stata's reclink package to match EEOC and NLRB records based on establishment name and street address. I kept matches with a match confidence of .9 or higher (see the reclink documentation for more details); hand-checking this group and removing some false positives left 6,223 matched cases.

Taken together, the NLRB and EEOC's data allow both fine-grained and broad exploration of the effects of bureaucracy on employment segregation, since they cover establishments across the United States. A further advantage when linking these data is that the EEOC's broad occupational categories correspond closely to the "bargaining unit type" categories tracked by the NLRB: both for example break out "Craft Workers" and "Professionals" from other job types. This is an advantage because many organizing drives cover a subset of the employees in the large

\footnotetext{
${ }^{4}$ Executive Order 11246, signed in 1965, extends the reporting requirement to firms with 50 or more employees if the firm has $\$ 50,000$ or more in federal government contract work annually.

${ }^{5}$ Including such establishments produces smaller effects of unionization when considering the full sample, which is in line with classical measurement error. It does not change the (null) results examined near the regression discontinuity.
} 
establishments monitored by the EEOC. The racial demography of work groups can vary considerably by job types within an establishment, and so relying solely on establishment-wide measures of workforce composition would introduce considerable measurement error (Tomaskovic-Devey et al. 2006). By focusing on the relevant job types, it is possible to construct more precise measures of workforce diversity.

To measure divergence between an establishment's workforce and its larger labor market, I use racial information given by annual respondents to the Current Population Survey. The CPS has long asked respondents to identify their race, as well as whether they identify as Hispanic. ${ }^{6}$ To build an annual demographic profile for each Metropolitan Statistical Area, I use all respondents between age 18 and 65 who identify themselves as in the labor force. Some organizing drives happen at large facilities that are outside MSAs, such as large meat-packing plants in rural Iowa or auto-parts plants in the North Carolina piedmont. Additionally, the CPS's sampling procedure can cause small MSAs to be poorly represented in some survey waves; drawing inferences about metropolitan populations from very small samples risks overstating the homogeneity of the population and thus biasing results. Excluding rural and small-city cases leaves 4,687 organizing drives that inform the analysis here. ${ }^{7}$

Such a sample is not perfectly representative of American workplaces. Most obviously, only certain industries are common targets of union organizing. By construction, these are larger establishments. The data are also disproportionately urban, though this bias is not large because MSAs are defined even on relatively small population clusters. Finally, the hostility toward unions in certain parts of the country means that pro-union regions like the northeast, the Great Lakes and the west coast are over-represented. Nor are these data representative of all union-organizing drives. These are the subset of such drives that affect large establishments only. Behavior may be quite different in these larger drives than in smaller campaigns, or indeed in campaigns that target

\footnotetext{
${ }^{6}$ Mapping respondents to races is often arbitrary and always fraught. The EEOC's survey forms break race into white, black, Hispanic, Asian American/Pacific Islander, and American Indian/Alaskan native. CPS respondents are asked about their race and their Hispanic identity in separate questions. Respondents can also list multiple races.

Nonetheless, 99.5 percent of respondents in the years in question listed a single race or "black-white," and more than 65 percent of the latter group identified as Hispanic. I therefore focused on single racial groups here. I classified black-white respondents who did not self-identify as Hispanic as black, on the presumption that this most closely reflects how American employers have historically classified and treated mixed-race workers.

7 Including rural establishments in analyses of managerial representation and occupational segregation produces substantively similar results to those presented here. Further models are available upon request.
} 
multiple, smaller establishments employing in aggregate the same number of workers as a single campaign in a large establishment.

Yet three factors should mitigate concerns of this sort. First and most importantly, the regression-discontinuity design described below estimates a "local average treatment effect," or the effect of treatment on the treated. This point should be stressed: this study does not try to explain why unions try to hold and win elections in some establishments rather than others. Unlike most work that uses union-representation election data (e.g., Heneman and Sandver 1983; Maranto and Fiorito 1987; Fiorito, Jarley, and Delaney 1995; Bronfenbrenner 1997; Riddell 2004; Ferguson 2008), I do not try to predict or model the success of particular campaigns. Quite the opposite: I focus on very close elections, those where success is least predictable. The point of doing so is that the lack of predictability lends support to the assumption of exogeneity. This in turn helps me to isolate the cause-and-effect relationship between unionization and employment composition as cleanly as possible. The trade-off in such a design is that it sacrifices some measure of generalizeability to better estimate causal effects on a well-specified sub-population. Second, while the design over-samples large establishments, most Americans work in large establishments. Indeed the idea of bureaucratic procedures guiding employment and the principle of a "representative" workforce both presume some degree of organizational scale (Reskin and Branch McBrier 2000). Previous research on bureaucratic employment practices in large organizations has relied on similar justifications for studying this organizational population (Fernandez and Weinberg 1997; Petersen and Saporta 2004; Kalev et al. 2006; Huffman et al. 2010). Third, and building on these two, generalizing from these to all union-organizing drives is not the goal of this study. The goal instead is to generalize from organizing drives in establishments that most resemble those studied in prior work on the impact of managerial diversity policies. For that generalization, this population of establishments that were both subject to the EEOC's reporting requirements and targeted for unionization is the right one.

\section{The Regression-discontinuity framework}

Regression discontinuity is at root an attempt to establish a believable counter-factual against which to compare the effect of a treatment (Morgan and Winship 2007). In this it resembles propensity-score matching (Piekes, Moreno, and Michael 2008), exact and coarsened-exact matching (Iacus, King, and Porro 2011), and other quasi-experimental designs that have been 
introduced over the last twenty years to support stronger causal identification. As with these other techniques, we conceive of the independent variable of interest-in this case, unionizationas a treatment that one group receives and the other does not. We can then examine the treatment effect by comparing the differences in group outcomes.

For causal identification, the treatment should be as exogenous as possible. In the ideal case, firms would be randomly ordered to enact policies that limit managerial discretion. Outcomes in these firms could then be compared to those in firms that had not enacted policies; and because the treatment was exogenous, we could attribute differences in outcomes to the treatment. Random assignment is not a realistic option in most organizational contexts, but we can approximate it with careful study design as long as certain assumptions hold.

Regression-discontinuity analysis has two main assumptions. First, the treatment should be a known, discontinuous function of an observed variable. Second, treatment should be a continuous function of other likely predictors (observed and unobserved) around the discontinuity's threshold. Van der Klaauw (2002) provides a classic example in his study of the effects of financial aid on academic performance. The causal problem he faced was that receiving financial aid was associated with better academic performance, but students have to demonstrate greater academic ability to receive aid. Van der Klaauw exploited the test-score requirements that many states use to award financial aid. Test scores are a continuous function of academic ability, but receipt of financial aid is discontinuous at a specified threshold. Presume that the cutoff is an SAT score of 1400. A student who scores 1600 likely has different (unobserved) ability than one who scores 1200, but a student who scores 1400 likely has comparable ability to one who scores a 1399. Yet one gets financial aid while the other does not. Thus, as long as one restricts the analysis to those cases very close to the treatment threshold, one can reasonably attribute outcome differences to the treatment rather than to differences in unobserved ability. Further, one can compare less-restrictive threshold cutoffs in order to test the sensitivity of the treatment effect to unobserved heterogeneity in the larger population.

Applying the regression-discontinuity framework to unionization is straightforward (DiNardo and Lee 2002). Whether a worker votes union is a well-studied function of many variables: the legal environment (Wessels 1981; Elliott and Huffman 1984), establishment size (Olson 1965; Farber 2001), the unemployment rate (Freeman 1998), employer responses (Freeman and Kleiner 1990; Fiorito and Bozeman 1997; Ferguson 2008), organizer tactics 
(Bronfenbrenner 1997; Bronfenbrenner and Hickey 2004), and so on. A worker's voting propensity is continuous, but the election result is a discontinuous outcome of the vote share the union receives. One vote over 50 percent makes all the difference. Establishments where unions win by a single vote should be comparable on other dimensions to establishments where unions lose by a single vote, and therefore we can attribute group differences in observed outcomes to the presence of the union.

More formally, suppose that the firm's level of employment discrimination, measured by an index $d$, depends on the function $d_{i}=\alpha+P_{i} \beta+X_{i} \gamma+\epsilon_{i}$, where $P_{i}$ indicates whether a policy that limits managerial discretion (affirmative action plans, for example) is in place, $X_{i}$ is a vector of observed and unobservable covariates (firm size, profitability, etc.) and $\epsilon_{i}$ is an error term. We want to estimate $\beta$, but a straight regression on the population will give biased results. Firms decide to adopt such policies based on some unobserved threshold function, which may itself be a function of $X_{i}$ :

$$
\begin{gathered}
P_{i}=1 \Leftrightarrow \tilde{V}_{i}>\tilde{V}^{*} \\
\tilde{V}_{i}=v\left(X_{i}\right)+M_{i} \theta+u_{i}
\end{gathered}
$$

where $\widetilde{V}_{i}$ is the unobserved threshold, $v(\cdot)$ is a function of $X_{i}$, and $M_{i} \theta$ represents other unobserved variables and their coefficients. Because $X_{i}$ factors into both the decision to adopt diversity training and the decision to hire more minorities, the composition of $X_{i}$ likely differs between firms that do and do not adopt training. Worse, because $X_{i}$ includes unobservable factors, we cannot determine the extent to which such unobserved heterogeneity biases our estimate of $\beta$.

Unlike many bureaucratic employment practices, unionization is a discontinuous function of vote share, which is observed:

$$
\begin{gathered}
\operatorname{UNION}_{i}=1 \Leftrightarrow V_{i}>\frac{1}{2} \\
V_{i}=v\left(X_{i}\right)+M_{i} \theta+u_{i}
\end{gathered}
$$

where $V_{i}$ is the vote share for the union. We still do not observe all of $X_{i}$, so fitting $d_{i}=\alpha+$ $U_{N I O N} \beta+X_{i} \gamma+\epsilon_{i}$ will still yield biased estimates of $\beta$. However, if $M_{i}$ is continuously distributed, then the composition of $X_{i}$ conditional on a win will be closer to the composition of $X_{i}$ conditional on a loss, the smaller the conditional vote margin $\delta$ is: 


$$
\lim _{\delta \rightarrow 0} \operatorname{Pr}\left(X_{i}=x \mid V_{i}=\frac{1}{2}+\delta\right)-\operatorname{Pr}\left(X_{i}=x \mid V_{i}=\frac{1}{2}-\delta\right)=0
$$

Prior work has used this fact to examine unions' impact on plant-closure rates (DiNardo and Lee 2002, 2004), firm profitability (Lee and Mas 2012), and pay dispersion (Frandsen 2012). DiNardo and Lee (2002) for example found that, while unionized establishments closed at higher rates than non-unionized ones, most of this effect was due to unionized plants' being older, more based in the manufacturing and blue-collar service sectors, and so on. Older plants were both more pro-union and more likely to fail. Examining close elections let them observe plants of comparable age and industrial composition-and showed no effects of unionization on plant closure. Lee and Mas (2012) in turn show that unionization has little effect on firm profitability when examining close elections, and demonstrate that the apparent union reduction of profits seen in their full sample stems from a negative relationship between cumulative abnormal returns and union vote share. Frandsen (2012) uses the same regression-discontinuity approach to explore the effects of unionization on wage distributions net of other variables, such as skill composition, that might also affect pay distribution, and finds both that unionizing raises the lower end of the pay scale and reduces employment among the least-skilled employees. Studies such as these rarely specify functional forms and estimates of $X_{i} \gamma$. Instead $\beta$ is measured directly as the between-group difference in $d$, the outcome of interest. I employ the same approach here.

\section{Calculating segregation}

I calculate three different measures of segregation: the share of black employees in managerial positions, an index of black-white dissimilarity (to measure occupational segregation) and a $\chi^{2}$ test of racial employment shares (to measure establishment segregation). Studies that use EE0-1 data to study bureaucracy's effect on employment segregation have tracked changes in the share of women and minorities in management (Kalev et al. 2006; Kalev 2009; see also Huffman et al. 2010). Employment shares of this type are intuitive and substantively important, yet only make sense if, at the start of the study period, the group in question is exclusively white and male. This holds well for managers but not for the rest of the workforce. Research that studies the racial make-up of entire establishments, such as Tomaskovic-Devey et al.'s (2006) documentation of trends in occupational segregation and Cohen et al.'s (2009) study of sex segregation in management, instead uses dissimilarity indices. Such an index reflects segregation or integration 
across the sub-units of a larger organization, but is independent of establishment segregation, or how representative the organization is of its larger environment.

These measures, then, are calculated differently and reflect separate but related concepts. Shares in management tell us something about the promotion prospects of specific groups but nothing about their isolation or integration in the broader firm. By comparison, a dissimilarity index considers groups that are clustered in sub-units that are nested in larger units, such as blacks and whites in census tracts in a city, or in departments in a firm. For groups $a$ and $b$, dissimilarity at time $t, d_{t}$, is defined as follows:

$$
d_{t} \equiv \frac{1}{2} \sum_{i}\left|\frac{a_{i t}}{A_{i t}}-\frac{b_{i t}}{B_{i t}}\right|
$$

where $a_{i t}$ is the share of group $a$ in sub-unit $i$ at time $t, A_{i t}$ is the share of group $a$ in the larger unit at time $t$, and so on. Intuitively, the index measures how many people would have to swap places in order to make the composition of the sub-units equal to the composition of the larger unit. When $d_{t}=0$, the racial make-up of any sub-unit matches the racial make-up of the organization as a whole. This does not mean though that the organization reflects its environment: if in a firm black workers make up exactly five percent of each department, but the firm operates in an urban area that is 40 percent black, then we might balk at calling the firm integrated. To measure establishment segregation, I generate expected frequencies for each racial group (white, black, Hispanic and Asian) based on the establishment's size and the racial composition of the firm's MSA. I then calculate $\frac{(\text { observed-expected })^{2}}{\text { expected }}$, the $\chi^{2}$ score for each racial group, and sum across races to produce an establishment-level $\chi^{2}$ score.

These three measures need not track in the same direction. Fundamentally the index of dissimilarity is changed by moving around existing workers within the firm, while the $\chi^{2}$ score is changed by moving workers into and out of the firm. An establishment can become more representative while remaining occupationally segregated and vice versa. We know that formal HR policies can have very different effects on hiring, retention, and promotion (Sørensen 2004; Fernandez and Mors 2008; Kalev 2009). It therefore makes sense to consider the impact of a workplace change like unionization on all of these dimensions.

Like most other employment practices, unionization mandates no immediate hiring or firing. Any impacts will happen over time, as workers enter or leave the establishment. I 
therefore track changes over time in these measures. For women and minority shares in management and occupational segregation, I calculate the mean statistics across establishments for units where the union organizing drive succeeded and for units where it failed. For establishment segregation, I calculate the mean score across MSAs for units where the drive succeeded and failed. I follow changes in these means for successive years after unionization for the full sample, and then contrast trends in the full sample with sub-samples restricted more and more closely around the 50-percent vote threshold, where unobserved heterogeneity is most restricted.

\section{Results}

\section{Descriptive statistics}

Table 1 reports the average share of blacks in managerial positions, black-white ${ }^{8}$ index of dissimilarity and $\chi^{2}$ score of establishment segregation for the full sample of matched establishments. I group establishment-year observations by the number of years that have passed since the organizing drive, since it makes more sense to consider for example all firms that have been organized for two years than all firms in 1997. We would not expect common effects across establishments in a calendar year, because establishments will have had unions in place (or not) for different lengths of time.

\section{[Table 1 about here]}

Three broad patterns are visible in table 1. First, there is an upward trend in the share of black managers over time in unionized establishments, while the trend in unsuccessfully organized establishments is basically flat. This trend, which also exists for women managers in unionized establishments, is similar to the relationship that Kalev et al. (2006) found between formal policies that establish organizational responsibility for diversity and female and minority representation, and echoes the effects of unionization on managerial composition that both Leonard (1985) and Kalev (2009) found. As mentioned, this effect might be in responses to changes in the non-managerial workforces, as firms promote from within or hire managers who share traits with the workforce. Another explanation, in line with the possibility of endogeneity, is

\footnotetext{
${ }^{8}$ Both shares of managerial employment and indexes of occupational segregation are based on two-group comparisons. Comparisons between whites and other groups, available on request, are qualitatively similar.
} 
that firms that are more receptive to promoting managerial diversity are also more receptive to unionization. It is notable for example that there is an initial difference in the average share of black managers in the two groups.

Second, establishment segregation of unionized establishments tends to decline sharply, relative to non-unionized ones. This integration of unionized establishments, relative to their larger labor markets, consists overwhelmingly of firms that are less diverse than the MSA becoming more heterogeneous, rather than "excessively" diverse firms becoming less heterogeneous; and the trend exists for firms that were unionized both with exceptionally high and exceptionally low shares of minority workers. Yet this decline in establishment segregation should be interpreted with caution, precisely because the places where organizing drives succeed appear to have quite different racial make-ups, on average, from firms where drives fail (as reflected in the shrinking differences between the groups over time). Differences in starting conditions like these augur that differences between the two groups of firms may predict both unionization and changes in workforce composition-the endogeneity described above.

Third, unionization seems to have no effect on occupational segregation. The index of black-white dissimilarity for both groups of establishments is stagnant over time. This reflects Tomaskovic-Devey et al.'s (2006) finding that, after making considerable progress in the 1960s and 1970s, occupational segregation stalled in the 1980s and 1990s. In a context like this, where establishment segregation is declining over time, unchanging occupational segregation implies that while such firms were hiring a more representative workforce, they tended to place blacks and whites into occupations where each group had already been over-represented.

Overall, table 1 suggests that establishments' racial make-up follows a different trend in the wake of a successful organizing drive than in the wake of a failed one. These are similar trends to what prior research into the effects of diversity policies that limit managerial discretion on workforce composition has found. Yet table 1 also shows that the establishments targeted by successful and unsuccessful organizing drives differ in their composition at the time they are targeted. This leaves open the possibility that some unobserved differences in the two groups of establishments affect both the success of union organizing and the make-up of the workforce over time. To investigate the possibility further, I zoom in on cases near the 50-percent vote threshold. 
Figure 1 shows the distribution of vote shares among the 4,687 elections studied here. The presence of many elections wherein the union received 100 percent of the vote (these tend to be small elections within large establishments) biases the distribution slightly away from normal, but otherwise the histogram is unimodal with a peak near 50 percent. Such a distribution helps the analysis because there are many cases close to the threshold itself, which allows for narrower standard errors, and it is easier to generalize from threshold cases to the larger population when the threshold lies near the population's center of mass. Simply stated, close union elections are not unusual union elections, which means that the cases with the best causal identification are typical of the whole.

[Figure 1 about here]

The regression-discontinuity design used here relies on the assumption that establishments that have very close union victories are similar on observed and unobserved characteristics to establishments that have very close union defeats. By definition, assessing balance on unobservables is impossible, but we can examine whether there are any discontinuities on relevant observable characteristics near the 50-percent vote threshold. Figures 2 and 3 present analyses for eight possible confounding variables. For each variable examined here, I estimate the local average for that variable among establishments where the union won 5 percent of the vote, 10 percent of the vote and so on, up to 100 percent. I also fit two cubic regressions to each variable, as a function of vote share: one regression is fit on cases where the vote share was less than 50 percent, while the other is fit on cases where the share was greater. Each panel plots the local averages and polynomial regression lines for one variable. If the two regression lines approach one another as the vote share approaches .5, then we can assume continuity around the threshold.

[Figure 2 about here]

[Figure 3 about here]

The first three panels of figure 2 show the average values of the outcome variables among different groups of elections. In each case, the observed and predicted values for each variable are very similar near the 50-percent threshold. The one possible exception is occupational segregation, where the fitted curves approach one another but from sharply different directions. This effect stems from the narrow range of occupational segregation observed in these data, which exaggerates the slope of the plotted curves. The difference in slopes is not statistically significant. 
The fourth panel of figure 2 shows that similar continuity exists in the racial composition of the areas where elections are held. Figure 3 compares other observable characteristics: the union density of the MSA, the size of the bargaining unit, the proportion of cases in manufacturing establishments, and the proportion in right-to-work states. Studies have found all of these factors correlated with election outcomes (see Heneman and Sandver 1983; Riddell 2004; and Ferguson 2008 for reviews), as indeed the curves in figures 2 and 3 suggest. In each of these cases though crossing the 50-percent threshold is not associated with a striking change in the level of the variable concerned-unlike unionization itself, which is a step function at 50 percent support. Other variables related to election success, such as the local unemployment rate, the party in control of state government and the distribution of unions involved all follow the same pattern (further analyses are available upon request). Together, these findings lend empirical support to the assumption that close union elections can be considered comparable on their observable and unobservable characteristics.

\section{Consequences of unionization}

Figure 4 explores the relationship between unionization and establishment segregation in greater detail. The top panel reproduces the findings from table 1: unionized establishments reduce their deviation from the larger labor market faster than non-unionized establishments do. Yet as figure 4 makes obvious, newly unionized establishments start out less representative on average.

Unionized establishments are not bounding ahead so much as catching up. Each panel shows time series for the same variable calculated on the subset of all cases where the vote share was within the indicated margin. Thus for example the bottom panel of figure 4 is based on the 283 cases where the union's share of the vote was between 48 and 52 percent (in a 50-person election, this equals a single vote). Standard errors are necessarily wider in a smaller group like this, but it is nonetheless striking how close the two group means are to one another over time. This sameness holds if we relax the bounds of comparison to a 6-percent margin, or even a 10-percent one (i.e., vote shares between 40 and 60 percent). It is difficult not to conclude that the apparent effects of unionization on establishment segregation in the top panel of figure 4 are due as much to the unrepresentative make-up of many places targeted by unions, places where the union vote share is particularly large or small, as to any limitations on managerial discretion that unionization imposes. 
[Figure 4 about here]

A similar result emerges from figure 5, which documents blacks' shares of managerial positions. In the full sample unionization increases the share of black managers, albeit from a higher starting point. This effect also vanishes when we focus on stricter sub-samples. Occupational segregation (figure 6) shows even smaller effects: while unionized firms present less occupational segregation in the full sample, this effect is not significant, and is reduced even further in the restricted samples.

[Figure 5 about here]

[Figure 6 about here]

Differences like these, where unions with particularly large or small vote shares behave differently from ones with shares near 50 percent, are critical for evaluating the likely influence of endogeneity through self-selection in a setting like this one. When we consider the top panel of figure 4, we could draw one of two conclusions. First, we might conclude that unionization reduces establishment-level segregation. Second, we might conclude that particularly segregated establishments are more likely to become unionized and to become more representative. If the latter conclusion is correct, then we cannot infer a causal relationship running from unionization's limiting managers' discretion to changes in workforce composition. The lower panels of figure 4 bear this out.

\section{Robustness checks}

Several robustness issues inhere in the assumptions of a regression-discontinuity study design and should be investigated. As discussed above, union-representation elections satisfy the assumptions that the treatment be discontinuous at a threshold, and that other observed variables be continuous at the threshold. A further advantage here is that the threshold itself lies near the center of the data, insofar as most union elections are fairly close. A third assumption is that treatment effects are constant across the treated subjects. A fourth is that the effect of the treatment is comparable near to and far from the threshold.

Regarding the third assumption, that of constant treatment effects across subjects, the chief concern is whether the closeness of the election results varies systematically with anything else. If for example union-representation elections were consistently closer in some industries than others, then zooming in on the regression-discontinuity threshold would entail focusing on a non- 
representative subset of the sample. Similarly, if union elections have grown closer over time, while union bargaining power has also been declining, then this secular trend could be mistaken for attenuation of effects due to eliminating self-selection.

In order to check issues such as these, I subset the data on several dimensions, and reproduced the analyses seen in figures 4,5 , and 6 . I separately analyzed manufacturing and service establishments, based on two-digit SIC codes; I also broke the data into six-year time periods, and examined different regions of the country separately. Sub-setting the data in this way involves sacrificing statistical power, so in several instances I observe no significant differences even when considering the full sample (this appears due to inflation of the standard errors, rather than large changes to the estimates themselves). Yet the general pattern remains unchanged: Any effects seen in the full sample disappear when focusing in on the 50-percent threshold. These analyses, which are available on request, suggest that the main result found here is not simply an artifact of specific time periods, industries, or regions.

I next explored the robustness of the fourth assumption, whether the effect of the treatment is comparable near to and far from the discontinuity threshold. The setting makes this a particular concern. Union elections by themselves do not substantially limit managers' discretion; the contracts negotiated in the wake of successful elections do. Contracts, though expected by the law, are by no means guaranteed. In a study of union-representation elections and first-contract negotiations between 1999 and 2004, Ferguson (2008) found that only 56 percent of all new bargaining units had negotiated a contract with their employer within a year of the election, rising to 84 percent within two years.

It is possible that, when and where the union secures a bare majority of the votes, the employer might perceive the union as weak and choose not to bargain with it in good faith. "Weak" unions would be less likely to win contracts and therefore less likely to affect workforce composition. This sequence of events would match the results I find here-effects in the full sample of elections that disappear when focusing closer to the 50-percent threshold-but not because of self-selection at the extremes of the vote distribution. Rather, effects would be attenuated closer to the discontinuity because of what we might call "non-compliance with the treatment" after close elections. This would not mean that this pattern of results in the unionelection data is inaccurate, but the different mechanism would limit the generalizability of these 
findings to other settings. It therefore should be investigated whether managers are in fact less likely to cooperate with unions after close elections.

There is very little systematic data on first-contract negotiations in the wake of these elections. The NLRB maintains records on the elections; another agency, the Federal Mediation and Conciliation Service (FMCS), is notified when a contract is set to expire. Initial contracts fall into a bureaucratic gap. The only systematic data on first contracts are those gathered by Ferguson (2008), who exploited an administrative initiative at the FMCS to obtain information on first-contract negotiations between 1999 and 2004. Fortunately, those data overlap with some of the data used here. I re-analyzed those data to see whether management behavior in the wake of a union election varied based on how close the election was, and compared outcomes for the subset of the cases present in both datasets. ${ }^{9}$

Figure 7 shows first-contract-agreement rates in the wake of union elections, broken into five-percent bins. First contracts were somewhat more likely where the union received between 90 and 95 percent of the vote. Yet in the establishments closest to the 50-percent threshold, first contracts were not significantly less likely than in establishments where the union received 100 percent of the vote. The overall correlation between vote share and the probability of a first contract is not significant.

[Figure 7 about here]

An additional indication of employer intransigence is whether the union files so-called 8(a)(5) charges against the employer during the bargaining period. The 8(a)(5) is a type of unfair labor practice charge accusing the employer of refusing to bargain in good faith with the union. Figure 8 shows these charge rates in the wake of elections, again broken out by five-percent bins. There is some evidence that charges are less likely when the union receives between 85 and 100 percent of the vote. Here, though, the unusual cases seem to be those where the union received high but not total support. There are for example no significant differences between establishments where the union received 50 percent of the vote and ones where it received 80

\footnotetext{
${ }^{9}$ Only a small fraction of the cases analyzed in Ferguson (2008) appear in my data set, because I focus on large establishments (over 100 employees) that were targeted by union organizing drives.
} 
percent. There is no indication in these data at least that employers act qualitatively different in establishments where the union received a slim majority of the votes. ${ }^{10}$

[Figure 8 about here]

Figures 7 and 8 summarize all available first-contract negotiations between 1999 and 2004. Several hundred of these establishments are large enough to appear in the main data analyzed here. Table 2 presents similar information on first-contract and 8(a)(5) charge rates for those establishments, organized by the vote share the union received. There are not enough cases here for formal statistical analyses, but inspection of the table will show that there is no pattern between vote share and either first-contract agreement or 8(a)(5) charges.

[Table 2 about here]

This comparison with prior work is of course imperfect. It would be better to have full information on employer responses in the wake of all the elections in the sample. Given the constraints on available data, though, these comparisons are among the best possible, and they do not indicate any qualitative differences in employer responses to "weak" union victories. Rather, employer responses seem to differ, where they do at all, near the extremes of positive union vote shares. Insofar as these are also the establishments with higher levels of segregation and greater shares of women and minorities in management to begin with, this pattern lends further support to the main finding that the impacts of unionization on workforce composition seem driven by self-selection into unionization by the employees of non-representative establishments.

\section{Discussion and conclusion}

Taken together, these results should give pause to proponents of policies that limit managers' discretion as a means to reduce employment segregation. I have argued that unionization can be compared in its effects to firm policies that limit managers' discretion regarding personnel decisions, and indeed I find effects on workforce composition on the full sample of union organizing drives that resemble those uncovered in prior work on both on unionization and on managerial diversity policies. Yet as the regression-discontinuity design reveals, these effects are not present among the cases nearer the 50-percent vote threshold. The absence of effects near

\footnotetext{
10 This should not necessarily be taken as good news. One way to read these results is that overwhelming employee
} support for a union does not make the typical employer any more likely to accept the union's legitimacy. 
this threshold suggests that the observed effects in these data are more likely to reflect selfselection into unionization than a causal effect from unionization itself.

It is important to be clear what these findings imply. The null result here does not imply that unionization has no effect. It is possible that, were establishments randomly unionized, we would observe more representative workforces and more diverse managers. That is to say, these findings do not undermine our theoretical reasons for expecting unionization to affect workforce composition. Rather, these findings imply that the "treatment" of unionization is sufficiently nonrandom that we cannot rule out the possibility that the full-sample effects stem from self-selection and not from the theoretical mechanisms. The study design reveals an absence of evidence, not evidence of absence. Nonetheless, this does imply that we cannot generalize from these data to say that unionization will, when applied to a randomly chosen firm, reduce employment discrimination therein.

It is on this point that we can draw a parallel to firms' diversity policies. It is quite possible that managerial diversity policies limit the discretionary decision-making by managers that might lead to biased decisions. It is therefore possible that formal personnel policies, accountability processes for managers, and monitoring of employment patterns to highlight and address disparities-all actions proposed in support of remedying workplace discrimination (Bielby 2000; Reskin 2003; Kalev et al. 2006) — do indeed remedy such discrimination. If they do, then an obvious implication is that, if policies that limit managerial discretion are applied to establishments that have not already adopted them, then the same reductions in bias and segregation will be observed. But we know that most establishments with these practices in place chose to adopt them. If their choice to adopt was endogenous to their desire to change their workforce composition, then we cannot infer a causal relationship between the practice and subsequent changes. In turn, we cannot assume that applying the same practices in other establishments will have the same effects. If we want to move beyond documenting associations between practices and outcomes and start claiming causal relationships, we need research that demonstrates the theorized effects while placing causal identification front-and-center. Unionization is an interesting case to consider in this light because the representation-election procedure makes a study design like this one possible.

It can and should be acknowledged that unions are an imperfect proxy for other employment practices that aim to reduce racial and sexual segregation. Unions have multiple 
goals, of which increasing the diversity of a given workforce is only one. It might be tempting to assume that unions do not affect workplace composition because, while unions do formalize the employment relationship, they do so in a fashion that directs managerial attention to wages, working conditions and other concerns that are not directly tied to diversity. Yet this assumption flies in the face of research that has documented unions' importance to non-white workers precisely because of their different impact on different races. It also begs the question why I find here that unionized establishments have experienced some of the same changes in workforce and managerial composition that firms with explicit practices meant to encourage equal opportunity have experienced (Dobbin 2009; Kalev 2009). This study suggests that those changes have more to do with unobserved heterogeneity among unionized and non-unionized firms than with unionization per se.

These findings should also be considered in light of previous work that has exploited union elections in a regression-discontinuity framework to identify causal effects. In most of those studies, theorized effects of unionization that appear in the full sample disappear when considering cases near the discontinuity threshold. Thus for example DiNardo and Lee (2002) found that the positive association between unionization and plant closure in their full sample disappears when zooming in on close elections. Given that this empirical approach has "banished" effects in multiple studies, it is reasonable to wonder whether there is something particular about unionization elections that makes this type of finding more likely, and that in turn makes generalizing from this context to others more fraught.

Addressing this potential limitation is beyond the scope of this study. However, some preliminary remarks are worth making. First, null results in regression-discontinuity designs like this one do not mean that the associations found in prior research were not really there; rather, they change our interpretation of those associations. Traditionally, the association between unions and plant closure was interpreted in terms of how unionization changed the day-to-day operations of the plant: the union raised operating costs and limited managerial flexibility to respond to environmental changes, thus making the firm less able to adapt to changing conditions. DiNardo and Lee's study suggested a different mechanism: firms that for various reasons have been adapting poorly to changing conditions are more likely to be targeted for unionization, and organizing drives there are more likely to succeed. Managements that are bad at managing employee discontent may also be bad at managing operations; thus we see a spurious association 
between unionization and plant closure. Similarly, in the cases I study here, there are real changes to workforce composition in the full sample. The lack of significance at the threshold though suggests that, as we devise mechanisms to explain that association, we should focus less on treatment effects than on selection effects. In short, what is it about a firm's observed employment composition that makes it more likely to become unionized, and how does that relate to subsequent composition?

A second remark on this score is that we have an increasing number of studies using union elections and regression discontinuities, studies in which previously noted effects seem to disappear. Yet the prominence of such null findings is in part due to contrast effects. Simply put, we do not yet have studies of managerial policies (or most other organizational phenomena) that make comparable attempts at causal identification. We thus cannot know whether disappearing effects would be more or less likely in other contexts. A strong alternative interpretation is likely: that diversity practices adopted by management are even more likely to be endogenous to the interests and goals of the firm than unionization is. Thus we might expect full-sample effects to disappear more often if we could in future studies control for the endogeneity of managerial practice.

Yet the risk of endogeneity might vary, depending on the practice. I only theorize indirect effects from unionization on workforce composition, and so it is worth carefully parsing the parallel between these cases and managerial policies. Prior work has focused both on managerial policies that involve explicit commitments to diversity and on policies that rationalize personnel practices and limit managerial discretion, without targeting diversity per se. Kalev et al.'s (2006) study for example found that policies that explicitly target diversity (such as mentorships and sensitivity trainings), but that do not create accountability or formal routines, have little effect on managerial composition. Similarly, much of the early work on the diffusion of diversity policies (Edelman 1990; Dobbin and Sutton 1998) argued that such policies were typically "ceremonial compliance" (Huffman 1995) that did not change internal practices. By contrast, Kalev (2009) finds that policies that break down previously sex-typed divisions of labor (Haveman, Broschak, and Cohen 2009) but that do not explicitly target diversity nonetheless increase female shares in management. Similarly, Castilla and Benard (2010) find that making managers aware of their own agency, rather than letting them make recourse to arguments of meritocracy, reduces discrimination in pay decisions. Because firms have an interest in the "window dressing" of 
diversity and equal opportunity, we might expect the greatest problems of endogeneity to be found among those firms that adopt policies limiting discretion alongside vocal claims about targeting diversity. By contrast, many of the indirect channels for addressing discrimination could be adopted to support other organizational goals (as is typically the case with many reorganizations). In such instances, particularly when discussions of diversity are not present, we might think self-selection less of a problem, because the decision to adopt is less correlated with an interest in changing composition. Ultimately, if we could jointly model the adoption and effects of such managerial practices, we could better assess their apparent causal effects as well.

Indeed such a model would further advance the marriage of research into the adoption and the impact of diversity policies. An obvious step for future research will be to build models of the adoption of diversity policies, then perform a matched-pair analysis of firms that could explore the effects of policies conditional on adoption. Such an approach cannot fully control for endogeneity, but it can offer a good estimate of the likely size of any bias. In particular, paying attention to the differences between policies that are explicitly adopted to affect workforce composition and policies that have indirect effects seems to offer a way to compare the relative bias introduced by self-selection. Similarly, future research on unionization should incorporate information about the other diversity practices that establishments have in place. The assumption in this study is that establishments where elections were close will be similar in their other human resource practices by virtue of the regression discontinuity design, but this could be investigated and such practices' interactions with unionization farther from the discontinuity could be explored.

These findings should somewhat call into question the prevailing theory that the formalization of employment policies reduces discrimination. That theory-that, whatever their weaknesses, formal bureaucracies are important tools for addressing the inequalities that social structure generates in the absence of formal structures-is one of organizational sociology's most fundamental insights. Precisely because the stakes are so high, in theoretical and indeed policy terms, we should be so concerned whether we can demonstrate the causal impact of such organizational policies. Archival studies may, ultimately, not be the way we do so, because of empirical confounds like self-selection; but that only forces researchers to consider other methods, like laboratory (Castilla and Benard 2010) and field experiments, that can potentially test the impact of theoretically relevant policies in more realistic settings. The rewards of doing so, both for theoretical development and public policy, would be considerable. 


\section{References}

Abraham, Katharine G. \& James L. Medoff. 1984. "Length of Service and Layoffs in Union and Nonunion Work Groups." Industrial and Labor Relations Review 38(1):87-97.

Baron, James N., Michael T. Hannan, Greta Hsu \& Özgecan Koçak. 2007. "In the Company of Women: Gender Inequality and the Logic of Bureaucracy in Start-Up Firms." Work and Occupations 34(1):35-66.

Baron, James N., P. Devereaux Jennings \& Frank R. Dobbin. 1988. “Mission Control? The Development of Personnel Systems in US Industry." American Sociological Review 53(4):497-514.

Baron, James N. \& William T. Bielby. 1985. Organizational Barriers to Gender Equality: Sex Segregation of Jobs and Opportunities. In Gender and the Life Course, ed. Alice S. Rossi. New York: Aldine pp. 233-251.

Bielby, William T. 2000. “Minimizing Workplace Gender and Racial Bias.” Contemporary Sociology 29:120-129.

Blank, Rebecca M., Marilyn Dabady \& Constance F. Citro, eds. 2004. Measuring Racial Discrimination. Washington, DC: The National Academies Press.

Botsch, Robert E. 1980. We Shall Not Overcome: Populism and Southern Blue-Collar Workers. Chapel Hill, NC: University of North Carolina Press.

Boyle, Kevin. 1995. The UAW and the Heyday of American Liberalism, 1945-1968. Ithaca, NY: Cornell University Press.

Bronfenbrenner, Kate. 1997. "The Role of Union Strategies in NLRB Certification Elections.” Industrial and Labor Relations Review 50(2):195-212.

Bronfenbrenner, Kate \& Robert Hickey. 2004. Changing to Organize: A National Assessment of Union Strategies. In Milkman \& Voss (2004).

Brudney, James J. 2005. Contractual Approaches to Labor Organizing: Supplanting the Election Paradigm? In Proceedings of the 57th Annual Meeting. Labor and Employment Relations Association pp. 106-113.

Budd, John W. 2004. Employment With a Human Face: Balancing Efficiency, Equity, and Voice. Ithaca, NY: ILR Press.

Castilla, Emilio J. 2008. “Gender, Race, and Meritocracy in Organizational Careers.” American Journal of Sociology 113(6):1479-1526.

Castilla, Emilio J. \& Stephen Benard. 2010. "The Paradox of Meritocracy in Organizations." Administrative Science Quarterly 55(4):543-576.

Chamberlain, Neil W. 1948. The Union Challenge to Management Control. New York: Harper.

Clawson, Dan. 2003. The Next Upsurge: Labor and the New Social Movements. Ithaca, NY: Cornell University Press.

Cohen, Philip N., Matt L. Huffman \& Stefanie Knauer. 2009. "Stalled Progress? Gender Segregation and Wage Inequality Among Managers, 1980-2000." Work and Occupations 36(4):318-342.

Cook, Clarissa \& Malcolm Waters. 1998. "The Impact of Organizational Form on Gendered Labour Markets in Engineering and Law." Sociological Review 46(2):314-339.

Dalton, Melville. 1959. Men Who Manage. New York: John Wiley and Sons.

DiNardo, John \& David S. Lee. 2002. The Impact of Unionization on Establishment Closure: A Regression Discontinuity Analysis of Representation Elections. Technical Report 8993. National Bureau of Economic Research. Cambridge, MA.

DiNardo, John \& David S. Lee. 2004. Unionism in California and the United States: Using Representation Elections to Evaluate Their Impact on Business Establishments. In 
Rebuilding Labor: Organizing and Organizers in the New Union Movement, ed. Ruth Milkman \& Kim Voss. Ithaca, NY: Cornell University Press chapter 9, pp. 251-293.

Dobbin, Frank. 2009. Inventing Equal Opportunity. Princeton, NJ: Princeton University Press.

Dobbin, Frank \& John R. Sutton. 1998. "The Strength of a Weak State: The Rights Revolution and the Rise of Human Resource Management Divisions." American Journal of Sociology 104:441- 476.

Dobbin, Frank, John Sutton, John Meyer \& W. Richard Scott. 1993. "Equal Opportunity Law and the Construction of Internal Labor Markets." American Journal of Sociology 99:396-427.

Eaton, Adrienne E. \& Jill Kriesky. 2001. "Union Organizing Under Neutrality and Card Check Agreements." Industrial and Labor Relations Review 55:42-59.

Edelman, Lauren B. 1990. "Legal Environments and Organizational Governance: The Expansion of Due Process in the American Workplace.” American Journal of Sociology 95(6):1401-1440.

Edelman, Lauren B. 1992. "Legal Ambiguity and Symbolic Structures: Organizational Mediation of Civil Rights Law.” American Journal of Sociology 97(6):1531-1576.

Edelman, Lauren B., Christopher Uggen \& Howard S. Erlanger. 1999. "The Endogeneity of Le- gal Regulation: Grievance Procedures as Rational Myth." American Journal of Sociology 105(2):406-454.

Edwards, Harry T. 1973. "The Emerging Duty to Bargain in the Public Sector." Michigan Law Review 71(5):885-934.

Elliott, Ralph D. \& James R. Huffman. 1984. "The Impact of Right-To-Work Laws on Employer Unfair Labor Practice Charges." Journal of Labor Research 5(2):165-176.

Elvira, Marta M. \& Christopher D. Zatzick. 2002. "Who's Displaced First? The Role of Race in Layoff Decisions." Industrial Relations 41(2):329-361.

Eren, Ozkan. 2007. "Measuring the Union/Non-Union Wage Gap Using Propensity Score Matching." Industrial Relations 46(4):766-780.

Fantasia, Rick \& Kim Voss. 2004. Hard Work: Remaking the American Labor Movement. Berkeley, CA: University of California Press.

Farber, Henry S. 2001. “Union Success in Representation Elections: Why Does Unit Size Matter?" Industrial and Labor Relations Review 54(2):329-348.

Ferguson, John-Paul. 2008. "The Eyes of the Needles: A Sequential Model of Union Organizing Drives, 1999-2004." Industrial and Labor Relations Review 62(1):3-21.

Fernandez, Roberto M. \& Marie Louise Mors. 2008. "Competing for jobs: Labor queues and gender sorting in the hiring process." Social Science Research 37:1061-1080.

Fernandez, Roberto M. \& Nancy Weinberg. 1997. "Sifting and Sorting: Personal Contacts and Hiring in a Retail Bank." American Sociological Review 62(6):883-902.

Fiorito, Jack \& D. P. Bozeman. 1997. "Fear and loathing (and bribery) in the workplace: worker perceptions of employer responses to union organizing." Journal of Individual Employment Rights 5:137-152.

Fiorito, Jack, Paul Jarley \& John Thomas Delaney. 1995. "National Union Effectiveness in Organizing: Measures and Influences." Industrial and Labor Relations Review 48(4):613-635.

Fiske, Susan T. 1998. Stereotyping, Prejudice and Discrimination. In Handbook of Social Psychology, ed. D. T. Gilbert, S. T. Fiske \& G. Lindzey. New York: McGraw-Hill pp. 357-411.

Foulkes, Fred K. 1980. Personnel Policies in Large Nonunion Companies. Englewood Cliffs, NJ: Prentice-Hall.

Frandsen, Brigham. 2012. "Why Unions Still Matter: The Effects of Unionization on the Distribution of Employee Earnings.” MIT Department of Economics Working Paper. 
Freeman, Richard B. 1998. Spurts in Union Growth: Defining Moments and Social Processes. In The Defining Moment: The Great Depression and the American Economy in the Twentieth Century, ed. Michael D. Bordo, Claudia Goldin \& Eugene N. White. Chicago: University of Chicago Press pp. 265-296.

Freeman, Richard B. \& Joel Rogers. 1999. What Workers Want. Ithaca, NY: ILR Press.

Freeman, Richard B. \& Morris M. Kleiner. 1990. "Employer Behavior in the Face of Union Organizing Drives." Industrial and Labor Relations Review 43(4):351-365.

Freeman, Richard \& James Medoff. 1984. What Do Unions Do? New York: Basic Books.

Frymer, Paul. 2007. Black and Blue: African Americans, the Labor Movement, and the Decline of the Democratic Party. Princeton, NJ: Princeton University Press.

Geoghegan, Thomas. 1991. Which Side Are You On? Trying to Be for Labor When It's Flat On Its Back. New York: Farrar Straus Giroux.

Griffith, Barbara S. 1988. The Crisis of American Labor: Operation Dixie and the Defeat of the CIO. Philadelphia: Temple University Press.

Halpern, Rick. 1997. Down on the Killing Floor: Black and White Workers in Chicago's Packinghouses, 1904-54. Urbana, IL: University of Illinois Press.

Haveman, Heather A., Joseph P. Broschak \& Lisa E. Cohen. 2009. Good Times, Bad Times: The Effects of Organizational Dynamics on the Careers of Male and Female Managers. In Research in the Sociology of Work, ed. Nina Bandelj. Vol. 18 of Research in the Sociology of Work Emerald Publishing Group pp. 119-148.

Heckscher, Charles C. 1988. The New Unionism: Employee Involvement in the Changing Corporation. New York: Basic Books.

Heneman, III, Herbert G. \& Marcus H. Sandver. 1983. "Predicting the Outcome of Union Certification Elections: A Review of the Literature." Industrial and Labor Relations Review 36(4):537- 559.

Huffman, Matt L. 1995. “Organizations, Internal Labor Market Policies, and Gender Inequality in Workplace Supervisory Authority." Sociological Perspectives 38(3):381-397.

Huffman, Matt L., Philip N. Cohen \& Jessica Pearlman. 2010. "Engendering Change: Organizational Dynamics and Workplace Gender Desegregation, 1975-2005." Administrative Science Quarterly 55:255-277.

Iacus, Stefano M., Gary King \& Giuseppe Porro. 2011. “Causal Inference without Balance Checking: Coarsened Exact Matching." Political Analysis. First published online 23 August 2011: doi:10.1093/pan/mpr013.

Isaac, Larry, Steve McDonald \& Greg Lukasik. 2006. “Takin' it from the Streets: How the Sixties Mass Movement Revitalized Unionization." American Journal of Sociology 112(1):46-96.

Jacoby, Sanford. 1985. Employing Bureaucracy. New York: Columbia University Press.

Kalev, Alexandra. 2009. "Cracking the Glass Cages? Restructuring and Ascriptive Inequality at Work." American Journal of Sociology 114(6):1591-1643.

Kalev, Alexandra, Frank Dobbin \& Erin Kelly. 2006. "Best Practice or Best Guesses? Diversity Management and the Remediation of Inequality." American Sociological Review 71:589617.

Kanter, Rosabeth. 1977. Men and Women of the Corporation. New York: Basic Books.

Kelly, Erin \& Frank Dobbin. 1999. "Civil Rights Law at Work: Sex Discrimination and the Rise of Maternity Leave Policies." American Journal of Sociology 105:455-492.

Kochan, Thomas, Harry Katz \& Robert McKersie. 1986. The Transformation of American Industrial Relations. Ithaca, NY: ILR Press. 
Lee, David S. \& Alexandre Mas. 2012. "Long-Run Impacts of Unions on Firms: New Evidence from Financial Markets, 1961-1999." Quarterly Journal of Economics 127(1):333-378.

Leonard, Jonathan S. 1985. "The Effect of Unions on the Employment of Blacks, Hispanics, and Women." Industrial and Labor Relations Review 39(1):115-132.

Lichtenstein, Nelson. 2002. State of the Union: A Century of American Labor. Princeton, NJ: Princeton University Press.

Maranto, Cheryl L. \& Jack Fiorito. 1987. "The Effect of Union Characteristics on the Outcome of NLRB Certification Elections." Industrial and Labor Relations Review 40(2):225-240.

Martin, Andrew W. 2008. "The Institutional Logic of Union Organizing and the Effectiveness of Social Movement Repertoires." American Journal of Sociology 113(4):1067-1103.

Mayo, Elton. 1984. Hawthorne and the Western Electric Company. In Organization Theory: Selected Readings, ed. D. S. Pugh. Second ed. New York: Penguin pp. 279-292.

McGuiness, Kenneth C. \& Jeffrey A. Norris. 1986. How to Take a Case Before the NLRB. Fifth ed. Washington: Bureau of National Affairs, Inc.

Milkman, Ruth. 1987. Gender at Work: The Dynamics of Job Segregation by Sex during World War II. Champaign, IL: University of Illinois Press.

Milkman, Ruth. 2006. L.A. Story: Immigrant Workers and the Future of the U.S. Labor Movement. New York: Russell Sage Foundation.

Milkman, Ruth \& Kim Voss, eds. 2004. Rebuilding Labor: Organizing and Organizers in the New Union Movement. Ithaca, NY: ILR Press.

Morgan, Stephen L. \& Christopher Winship. 2007. Counterfactuals and Causal Inference: Methods and Principles for Social Research. New York: Cambridge University Press.

Nelson, Bruce. 1992. "Class and Race in the Crescent City: The ILWU, from San Francisco to New Orleans." In The CIO's Left-Led Unions, ed. Steve Rosswurm. New Brunswick, NJ: Rutgers University Press pp. 19-46.

Nelson, Bruce. 2001. Divided We Stand: American Workers and the Struggle for Black Equality. Princeton: Princeton University Press.

Olson, Mancur. 1965. The Logic of Collective Action: Public Goods and the Theory of Groups. Cambridge, MA: Harvard University Press.

Peikes, Deborah N., Lorenzo Moreno \& Sean Michael. 2008. "Propensity Score Matching: A Note of Caution for Evaluators of Social Programs.” American Statistician 62(3):222-231.

Perrow, Charles. 1986. Complex Organizations: A Critical Essay. New York: Random House.

Petersen, Trond \& Ishak Saporta. 2004. "The Opportunity Structure for Discrimination." American Journal of Sociology 109(4):852-901.

Piore, Michael J. \& Sean Safford. 2006. “Changing Regimes of Workplace Governance, Shifting Axes of Social Mobilization, and the Challenge to Industrial Relations Theory." Industrial Relations 45(3):299-325.

Reskin, Barbara \& Debra Branch McBrier. 2000. "Why Not Ascription? Organizations' Employment of Male and Female Managers." American Sociological Review 64:210-233.

Reskin, Barbara F. 2000. "The Proximate Causes of Employment Discrimination.” Contemporary Sociology 29:319-328.

Reskin, Barbara F. 2003. "Including Mechanisms in Our Models of Ascriptive Inequality." American Sociological Review 68:1-21.

Reskin, Barbara \& Patricia Roos. 1990. Job Queues, Gender Queues: Explaining Women's Inroads into Male Occupations. Philadelphia, PA: Temple University Press. pp. 3-68.

Riddell, Chris. 2004. "Union Certification Success Under Voting Versus Card-Check Procedures: 
Evidence from British Columbia, 1978-1998." Industrial and Labor Relations Review 57(4):493- 517.

Robinson, Corre, Tiffany Taylor, Donald Tomaskovic-Devey, Catherine Zimmer \& Matthew W. Irvine Jr. 2005. "Studying Race/Ethnic and Sex Segregation at the Establishment Level: Methodological Issues and Substantive Opportunities Using EEO-1 Reports." Work and Occupations 32:5-38.

Rosenfeld, Jake \& Meredith Kleykamp. 2009. “Hispanics and Organized Labor in the United States, 1973 to 2007." American Sociological Review 74(6):916-937.

Rosenfeld, Jake \& Meredith Kleykamp. 2012. "Organized Labor and Racial Wage Inequality in the United States." American Journal of Sociology 117(5):1460-1502.

Schuwerk, Robert P. 1972. "The Philadelphia Plan: A Study in the Dynamics of Executive Power." The University of Chicago Law Review 39(4):723-760.

Scott, James C. 1998. Seeing Like a State: How Certain Schemes to Improve the Human Condition Have Failed. New Haven, CT: Yale University Press.

Scott, W. Richard \& Gerald F. Davis. 2006. Organizations and Organizing: Rational, Natural and Open Systems. New York: Pearson.

Slichter, Sumner H., James J. Healy \& E. Robert Livernash. 1960. The Impact of Collective Bargaining on Management. Washington, DC: Brookings Institution.

Sørensen, Jesper B. 2004. "The Organizational Demography of Racial Employment Segregation.” American Journal of Sociology 110(3):626-671.

Sørensen, Jesper B. \& Amanda J. Sharkey. 2011. "The Perils of False Certainty: A Comment on the ASA Amicus Brief in Dukes v. Wal-Mart." Sociological Methods and Research 40(4):635-645. Tomaskovic-Devey, Donald. 1993. Gender and Racial Inequality at Work. Ithaca, NY: ILR Press.

Tomaskovic-Devey, Donald, Catherine Zimmer, Kevin Stainback, Corre Robinson, Tiffany Taylor \& Tricia McTague. 2006. "Documenting Desegregation: Segregation in American Workplaces by Race, Ethnicity, and Sex, 1966-2003.” American Sociological Review 71:565-588.

Vallas, Steven P. 2003. "Why Teamwork Fails: Obstacles to Workplace Change in Four Manufacturing Plants." American Sociological Review 68(2):223-250.

Van der Klaauw, Wilbert. 2002. "Estimating the effect of financial aid offers on college enrollment: A regression-discontinuity approach." International Economic Review 43(4):1249-1287.

Weber, Max. 1968. "Bureaucracy." In Economy and Society: An Outline of Interpretive Sociology, ed. Guenther Roth \& Claus Wittich. Vol. 3 Bedminster Press pp. 956-969.

Wessels, Walter J. 1981. "Economic Effects of Right to Work Laws.” Journal of Labor Research 2(1):55-75.

Zeiger, Robert H., ed. 1986. American Workers, American Unions, 1920-1985. Baltimore, MD: Johns Hopkins University Press. 


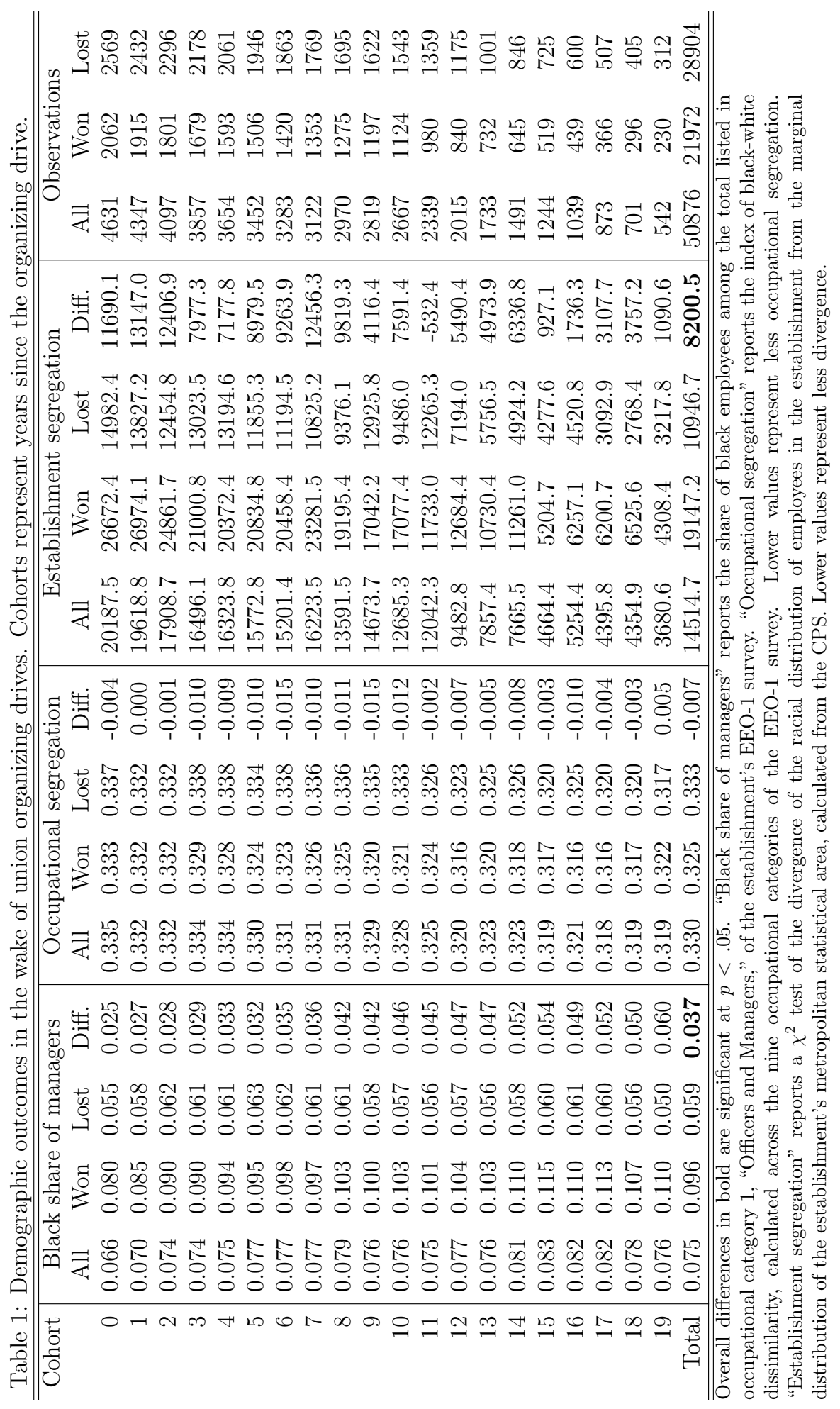


Table 2: Comparison of first-contract-agreement rates and 8(a)(5) Unfair Labor Practice charge rates by share of election vote received. The 240 cases tabulated here were matched with information on first-contracts and ULP charges in the data used by Ferguson (2008). Proportions are shown below counts.

\begin{tabular}{|c|c|c|c|c|}
\hline \multirow[t]{2}{*}{ Vote share } & \multicolumn{2}{|c|}{ First contract reached? } & \multicolumn{2}{|c|}{ 8(a)(5) ULP charge filed? } \\
\hline & No & Yes & No & Yes \\
\hline \multirow[t]{2}{*}{50} & 8 & 4 & 11 & 1 \\
\hline & .67 & .33 & .92 & .08 \\
\hline \multirow[t]{2}{*}{55} & 13 & 12 & 22 & 3 \\
\hline & .52 & .48 & .88 & .12 \\
\hline \multirow[t]{2}{*}{60} & 15 & 21 & 31 & 5 \\
\hline & .42 & .58 & .86 & .14 \\
\hline \multirow[t]{2}{*}{65} & 7 & 12 & 18 & 1 \\
\hline & .37 & .63 & .95 & .05 \\
\hline \multirow[t]{2}{*}{70} & 7 & 3 & 9 & 1 \\
\hline & .7 & .3 & .90 & .10 \\
\hline \multirow[t]{2}{*}{75} & 4 & 12 & 16 & 0 \\
\hline & .25 & .75 & 1.00 & .00 \\
\hline \multirow[t]{2}{*}{80} & 15 & 7 & 21 & 1 \\
\hline & .68 & .32 & .95 & .05 \\
\hline \multirow[t]{2}{*}{85} & 6 & 15 & 20 & 1 \\
\hline & .29 & .71 & .95 & .05 \\
\hline \multirow[t]{2}{*}{90} & 5 & 2 & 6 & 1 \\
\hline & .71 & .29 & .86 & .14 \\
\hline \multirow[t]{2}{*}{95} & 4 & 1 & 5 & 0 \\
\hline & .8 & .2 & 1.00 & .00 \\
\hline \multirow[t]{2}{*}{100} & 28 & 39 & 62 & 5 \\
\hline & .42 & .58 & .93 & .07 \\
\hline \multirow[t]{2}{*}{ Total } & 112 & 128 & 221 & 19 \\
\hline & .47 & .53 & .92 & .08 \\
\hline
\end{tabular}




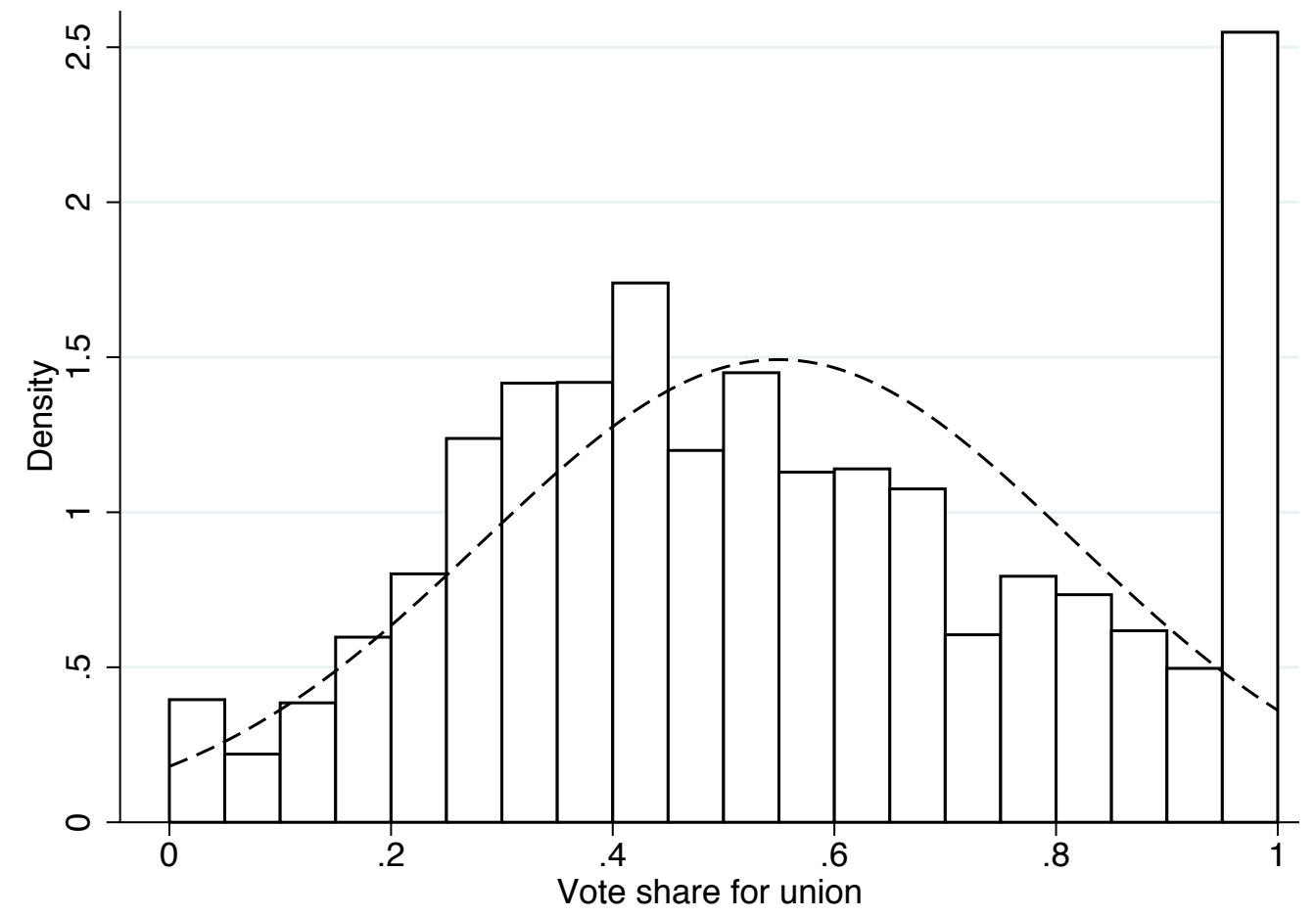

Figure 1: Distribution of vote shares in large establishment union-representation elections, 1984 2008. 

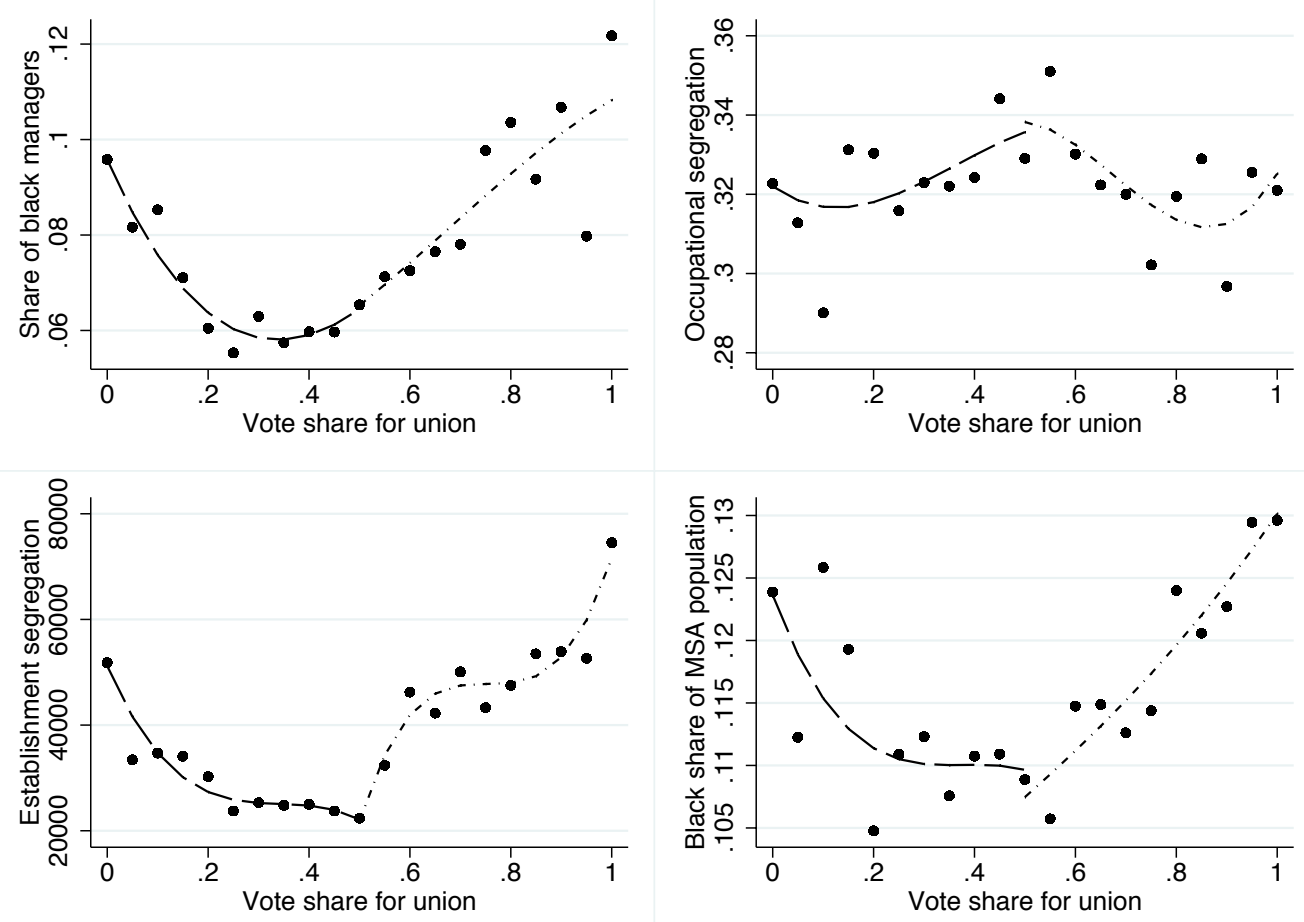

Figure 2: Inspecting the validity of the regression-discontinuity assumption. Each panel plots local averages for the response variable at 5-percent intervals of union vote share, as well as cubic regression lines fitted to the data above and below the 50-percent threshold. Continuity can be assumed when the regression lines approach one another near the threshold, as they do in each case here. 

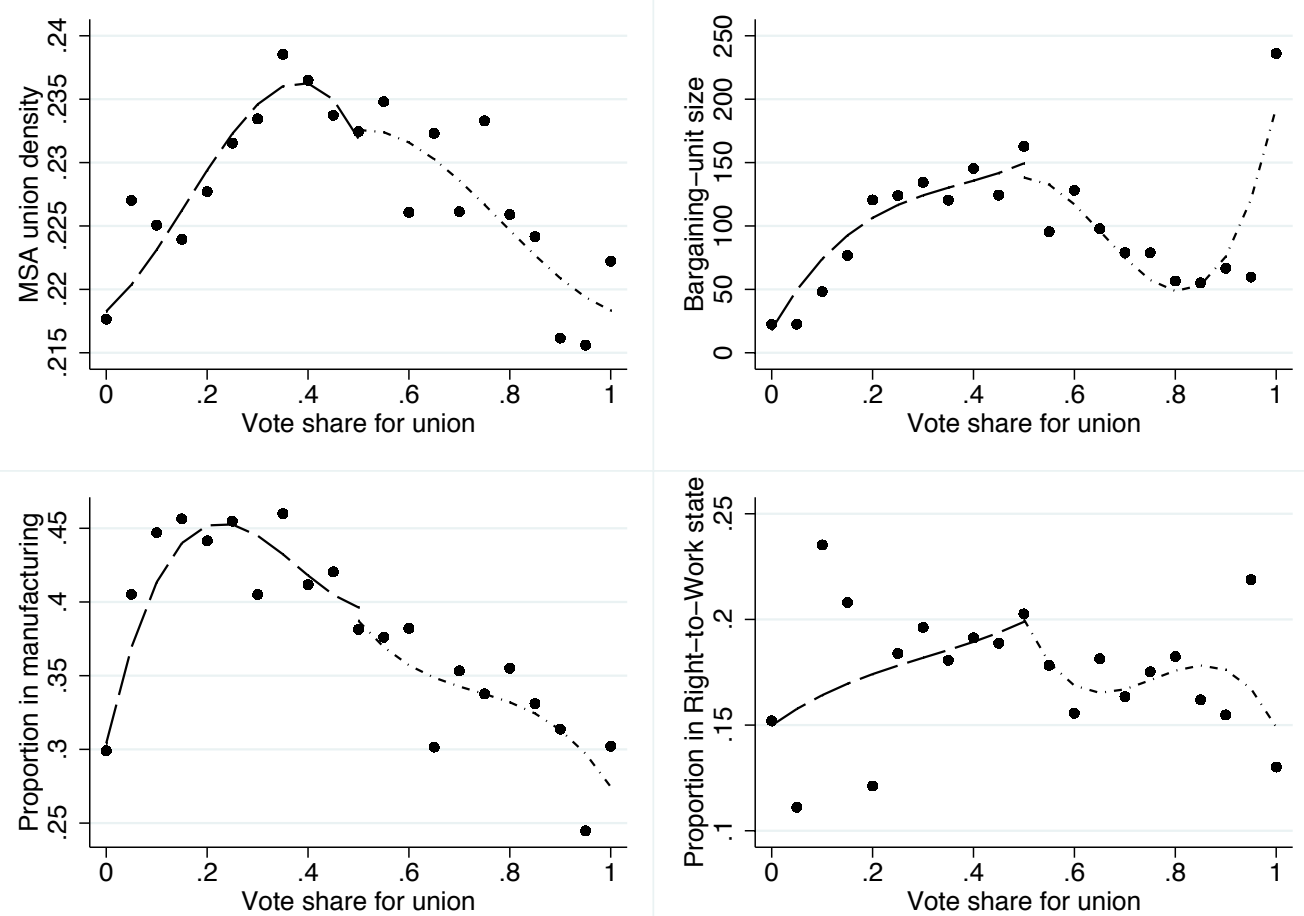

Figure 3: Inspecting the validity of the regression-discontinuity assumption, continued. Panels are constructed as in figure 2 . 

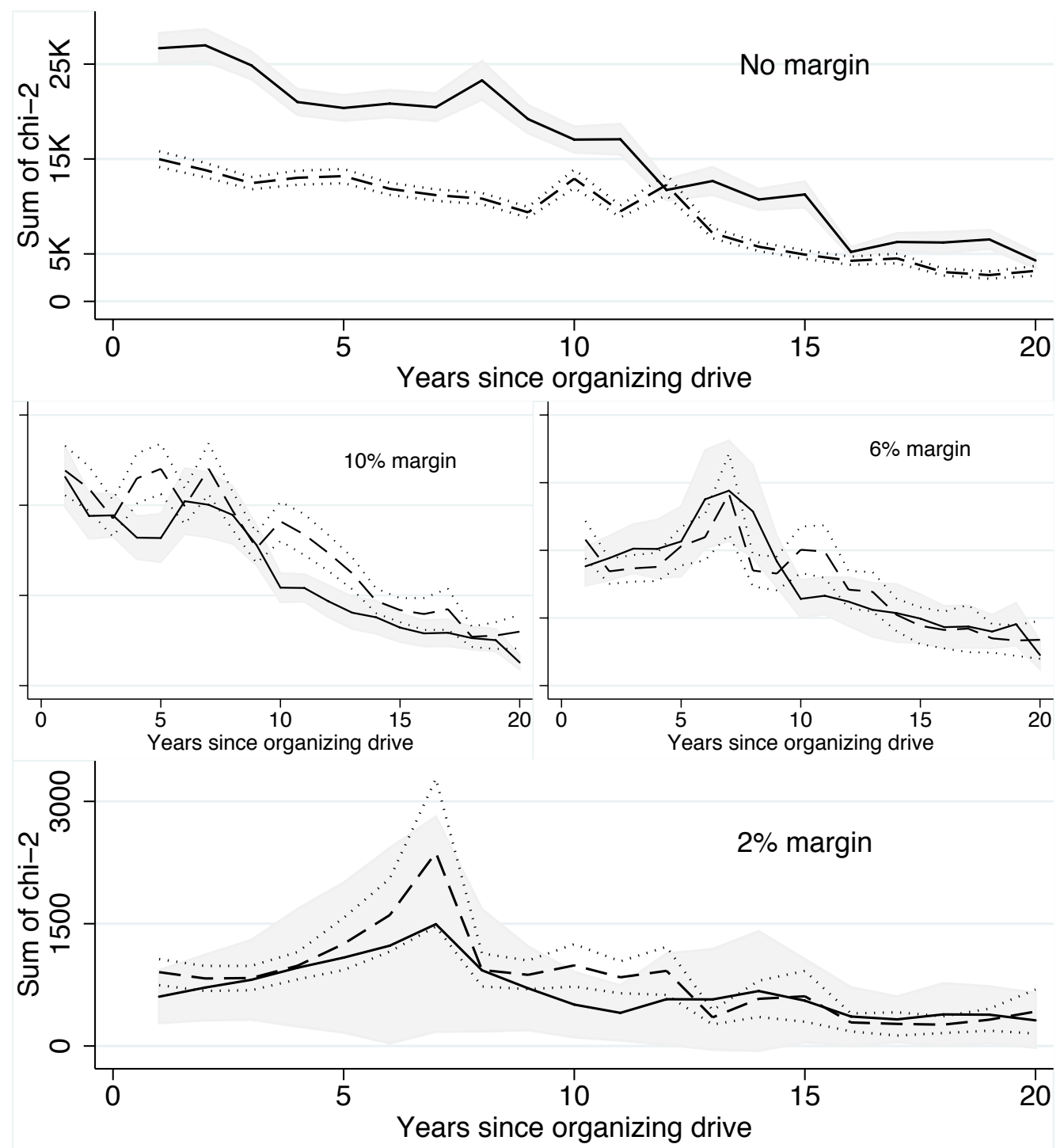

Figure 4: Comparison of unionization's effect on establishment segregation, using increasingly strict sub-samples to exploit the regression-discontinuity design. In each panel, the solid line and corresponding interval represent those establishments where a union organizing drive succeeded within the specified margin; the broken line and confidence interval are establishments where a drive failed. Sum of $\chi^{2}$ is dependent on population size, so the absolute heights of the curves are not directly comparable, although slopes are. 

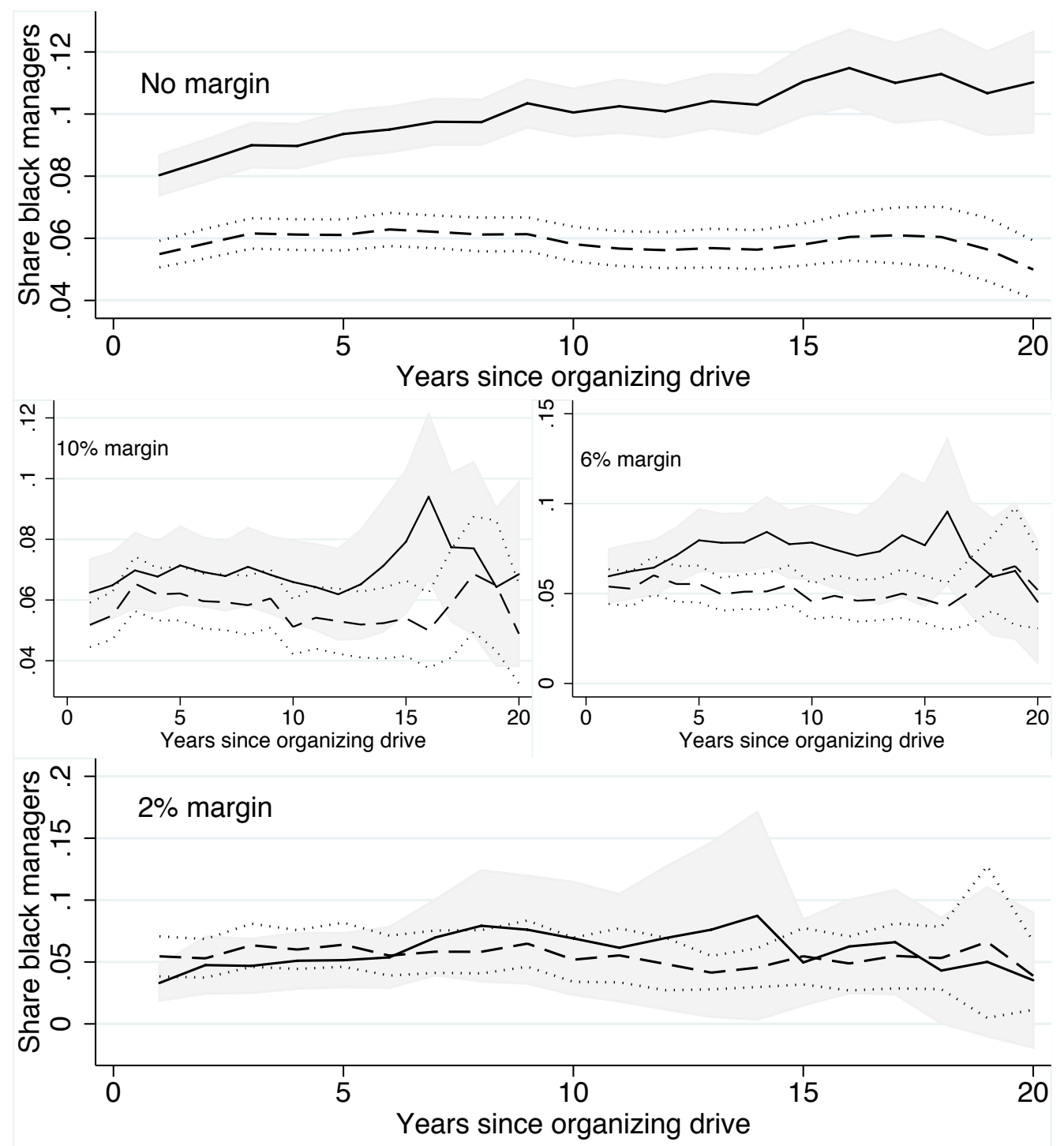

Figure 5: Comparison of unionization's effect on blacks' share of managerial positions, using increasingly strict sub-samples to exploit the regression-discontinuity design. 

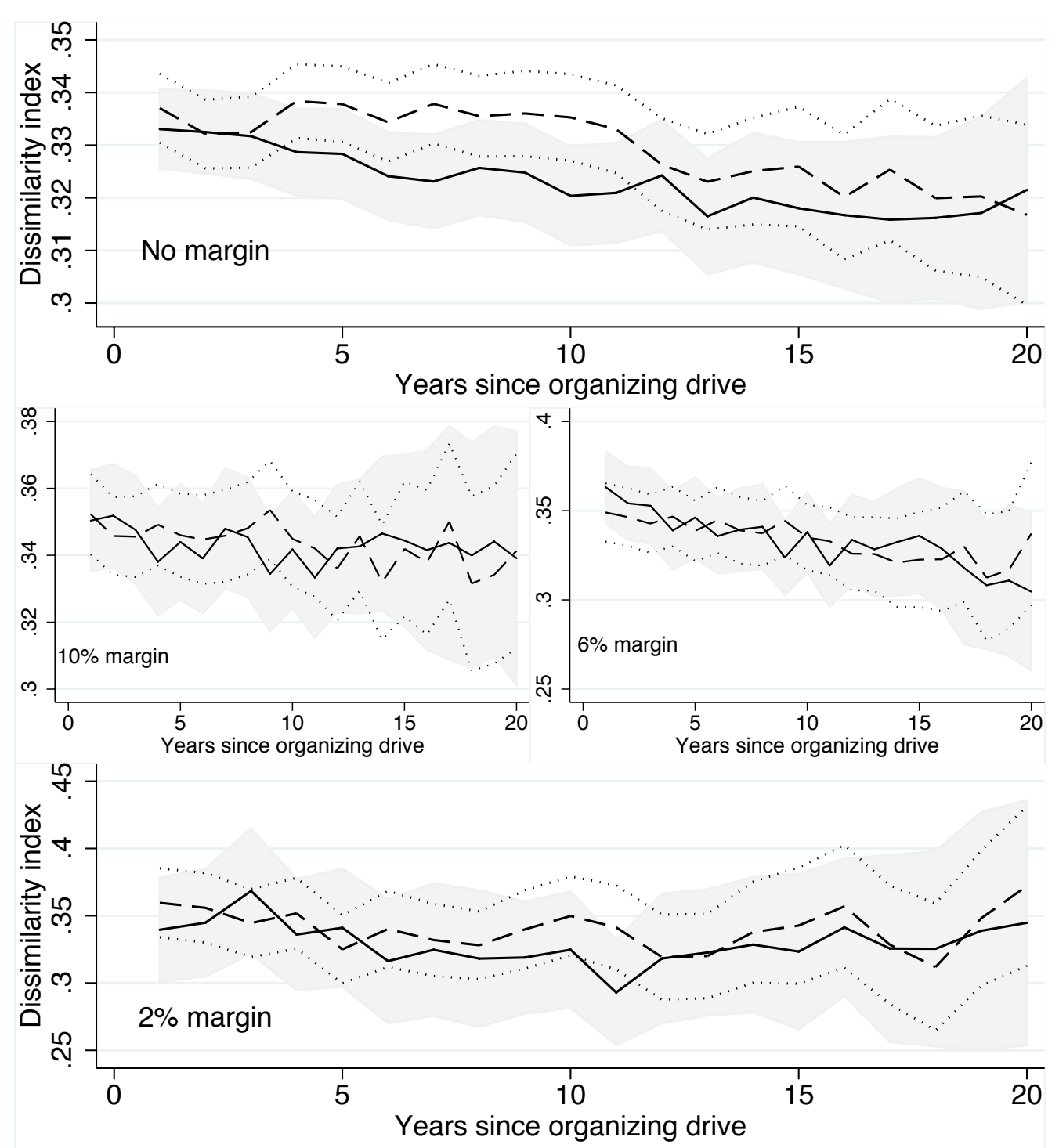

Figure 6: Comparison of unionization's effect on occupational segregation, using increasingly strict sub-samples to exploit the regression-discontinuity design. 


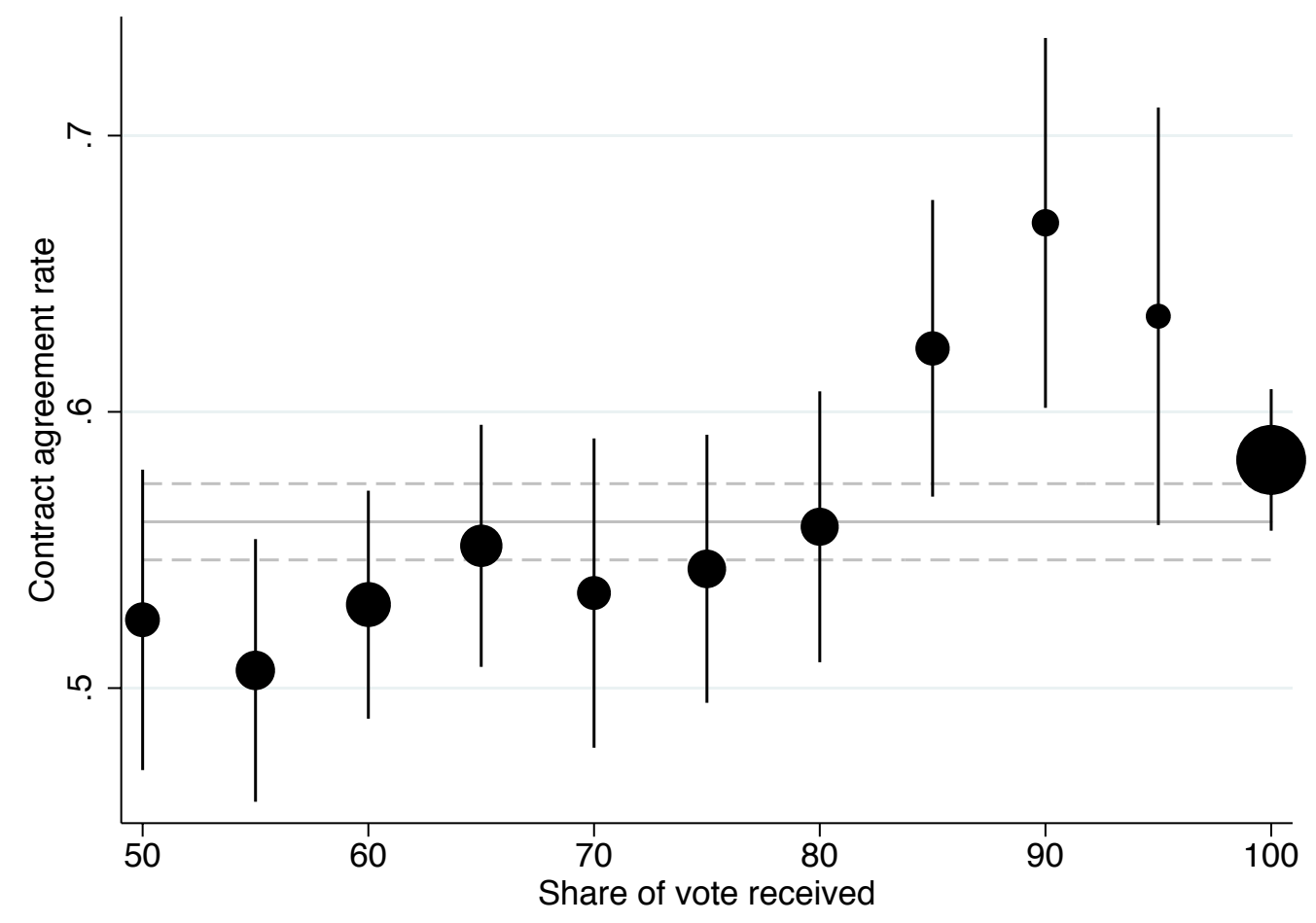

Figure 7: First-contract agreement rates in the wake of 4,991 union-representation elections between 1999 and 2004, broken out by the share of the vote the union received in the election. Points are scaled by the number of cases in that vote-share bin. Data are taken from Ferguson (2008). 


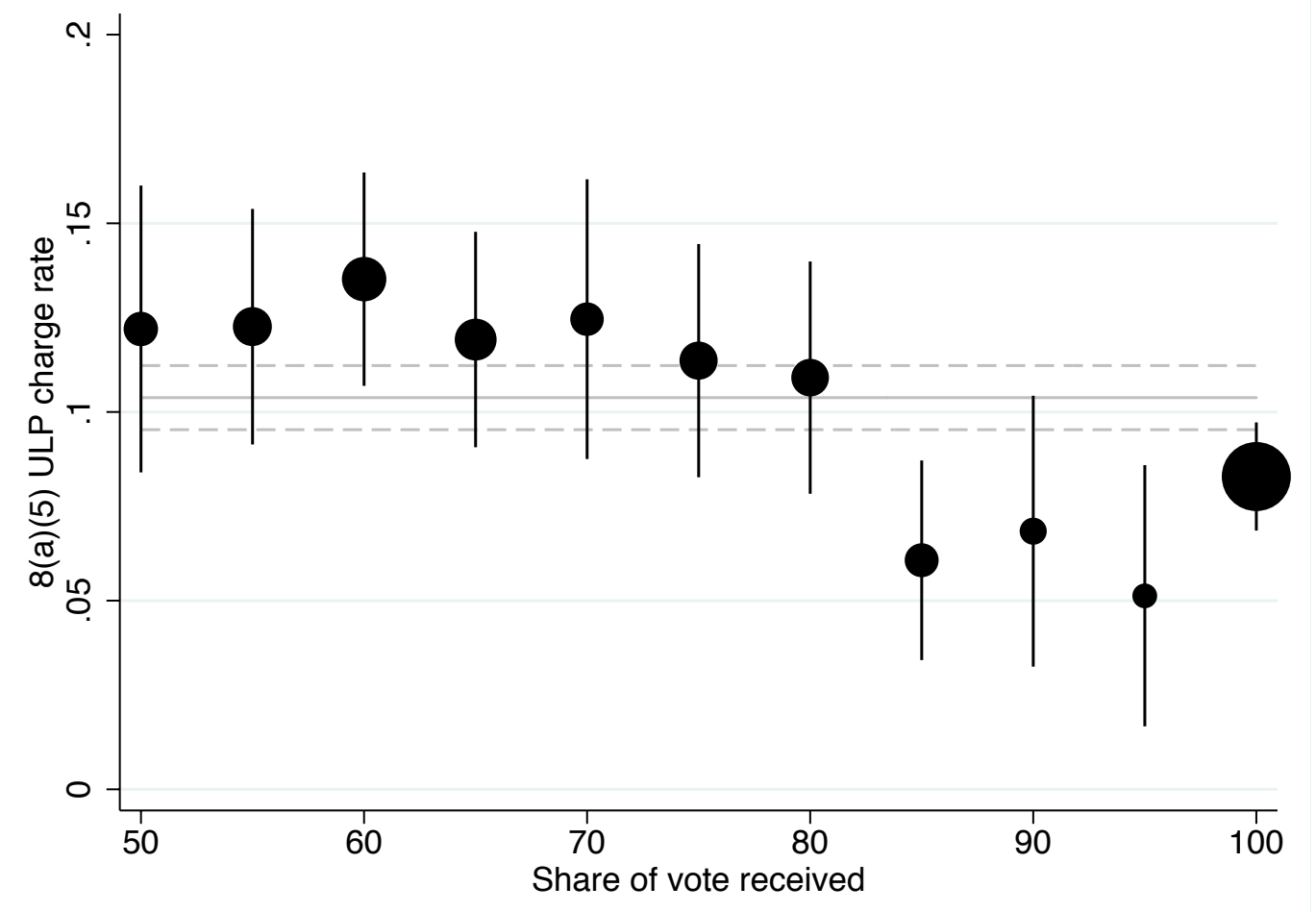

Figure 8: 8(a)(5) unfair labor practice-charge rates in the wake of union-representation elections, broken out by the share of the vote the union received in the election. Data are taken from Ferguson (2008). 